\title{
Atmospheric wet and litterfall mercury deposition at urban and rural sites in China
}

\author{
Xuewu Fu ${ }^{1}$, Xu Yang ${ }^{1,2}$, Xiaofang Lang ${ }^{1,2}$, Jun Zhou ${ }^{1,2}$, Hui Zhang ${ }^{1}$, Ben Yu ${ }^{1}$, Haiyu Yan ${ }^{1}$, Che-Jen Lin ${ }^{1,3,4}$, and \\ Xinbin Feng ${ }^{1}$ \\ ${ }^{1}$ State Key Laboratory of Environmental Geochemistry, Institute of Geochemistry, Chinese Academy of Sciences, 99 \\ Lincheng West Road, Guiyang, 550081, China \\ ${ }^{2}$ Key Laboratory of Karst Environment and Geohazard Prevention, Guizhou University, Ministry of Education, Guiyang, \\ 550003, China \\ ${ }^{3}$ Department of Civil and Environmental Engineering, Lamar University, Beaumont, Texas 77710, USA \\ ${ }^{4}$ Center for Advances in Water and Air Quality, Lamar University, Beaumont, Texas 77710, USA
}

Correspondence to: Xinbin Feng (fengxinbin@vip.skleg.cn)

Received: 14 June 2016 - Published in Atmos. Chem. Phys. Discuss.: 20 June 2016

Revised: 26 August 2016 - Accepted: 27 August 2016 - Published: 19 September 2016

\begin{abstract}
Mercury ( $\mathrm{Hg})$ concentrations and deposition fluxes in precipitation and litterfall were measured at multiple sites (six rural sites and an urban site) across a broad geographic area in China. The annual deposition fluxes of $\mathrm{Hg}$ in precipitation at rural sites and an urban site were 2.0 to 7.2 and $12.6 \pm 6.5 \mu \mathrm{g} \mathrm{m}^{-2} \mathrm{yr}^{-1}$, respectively. Wet deposition fluxes of $\mathrm{Hg}$ at rural sites showed a clear regional difference with elevated deposition fluxes in the subtropical zone, followed by the temporal zone and arid/semi-arid zone. Precipitation depth is the primary influencing factor causing the variation of wet deposition. $\mathrm{Hg}$ fluxes through litterfall ranged from 22.8 to $62.8 \mu \mathrm{g} \mathrm{m}^{-2} \mathrm{yr}^{-1}$, higher than the wet deposition fluxes by a factor of 3.9 to 8.7 and representing approximately $75 \%$ of the total $\mathrm{Hg}$ deposition at the forest sites in China. This suggests that uptake of atmospheric $\mathrm{Hg}$ by foliage is the dominant pathway to remove atmospheric $\mathrm{Hg}$ in forest ecosystems in China. Wet deposition fluxes of $\mathrm{Hg}$ at rural sites of China were generally lower compared to those in North America and Europe, possibly due to a combination of lower precipitation depth, lower GOM concentrations in the troposphere and the generally lower cloud base heights at most sites that wash out a smaller amount of GOM and PBM during precipitation events.
\end{abstract}

\section{Introduction}

Mercury $(\mathrm{Hg})$, especially its methylated form, is a potent neurotoxin to humans and wildlife. Because of its high volatility, mild reactivity, and water solubility, gaseous elemental mercury (GEM) is the dominant (>75\%) form of total Hg in the atmosphere (Sprovieri et al., 2010; Gustin et al., 2015; Shah et al., 2016), while the majority of the remaining fractions of $\mathrm{Hg}$ in the atmosphere are gaseous oxidized mercury (GOM) and particulate bound mercury (PBM), which are operationally defined. GEM has an atmospheric residence time of several months to a year and therefore spreads globally before being converted to other forms and deposited to the earth's surface (Holmes et al., 2010; Driscoll et al., 2013; Amos et al., 2015). On the other hand, GOM and PBM have much higher water solubility and reactivity, and are readily deposited via wet and dry deposition pathways.

Quantifying the relationship between atmospheric $\mathrm{Hg}$ depositions and emissions is of prime importance in its global biogeochemical cycle. $\mathrm{Hg}$ in the atmosphere could be from anthropogenic and natural emission sources. At a global scale, direct and legacy anthropogenic emissions represent the predominant $(\sim 2 / 3)$ sources of $\mathrm{Hg}$ in the atmosphere (Seigneur et al., 2004; Selin et al., 2007; Pirrone et al., 2010), and account for most of the deposition of $\mathrm{Hg}$ to the earth's surface (Selin et al., 2008; Amos et al., 2013). Hg is removed from the atmosphere through wet deposition and dry deposition pathways. Atmospheric $\mathrm{Hg}$ deposition networks have 
been established in North America (NADP, 1994) and Europe (EMEP). These networks provided critical databases on the spatial and temporal trends in $\mathrm{Hg}$ wet deposition and help to constrain the regional and global atmospheric $\mathrm{Hg}$ deposition budget (Selin et al., 2007; L. Zhang et al., 2012). Dry deposition of atmospheric $\mathrm{Hg}$, including uptake of GEM by vegetation and dry deposition of GOM/PBM, is considered to be more important than wet deposition in the total $\mathrm{Hg}$ deposition budget (Dastoor and Larocque, 2004; Selin et al., 2007). However, dry deposition of $\mathrm{Hg}$ is difficult to be quantified accurately because of the lack of proper measurement techniques. Recently, an increasing number of studies have suggested that measurements of litterfall (uptake of total gaseous mercury - TGM) and throughfall (washout of GOM and PBM deposited to foliage surfaces) could be a good indicator of $\mathrm{Hg}$ dry deposition to forest ecosystems (Johnson and Lindberg, 1995; St. Louis et al., 2001; Gustin, 2012). Also, empirical models have been developed to quantify dry deposition of $\mathrm{Hg}$ to various landscapes (Lyman et al., 2007; L. Zhang et al., 2012). Although subjected to some bias (Zhang et al., 2009; Gustin et al., 2015), these studies significantly improved our understanding of the role of dry deposition in the global $\mathrm{Hg}$ biogeochemical cycle.

China is the largest source region of atmospheric $\mathrm{Hg}$ in the world. Recent studies revealed that $\mathrm{Hg}$ emissions from anthropogenic and natural sources in China were in the range of 800-1200t (Shetty et al., 2008; S. X. Wang et al., 2014; Fu et al., 2015a; Wang et al., 2016), approximately 1/6 of the global $\mathrm{Hg}$ emissions into the atmosphere (Pirrone et al., 2010; Song et al., 2015). The large emissions in China not only have an impact on the domestic $\mathrm{Hg}$ pollution ( $\mathrm{Fu}$ et al., 2015 b), but also have the potential to enhance atmospheric $\mathrm{Hg}$ concentration and deposition elsewhere (Seigneur et al., 2004; Strode et al., 2008; Durnford et al., 2010). To construct the mass budget of $\mathrm{Hg}$ in China, measurements of atmospheric $\mathrm{Hg}$ wet and dry deposition are essential. However, studies of wet and dry deposition in China are rather limited. Most of the previous studies in China were conducted either at a single site using bulk collectors or mostly in urban areas (Guo et al., 2008; Wang et al., 2009; Y. M. Wang et al., 2014; Fu et al., 2010b; Zhou et al., 2013; Xu et al., 2014; Zhu et al., 2014), which are not sufficient to depict the overall pattern of atmospheric $\mathrm{Hg}$ deposition in China. In the present study, we conducted comprehensive measurements of wet and litterfall deposition fluxes of $\mathrm{Hg}$ at multiple sites (six rural sites and one urban site) across a broad geographic area in mainland China. This study aims to better understand the spatial distributions of $\mathrm{Hg}$ deposition and mass balance of atmospheric $\mathrm{Hg}$ in China. We also compared these fluxes to previous observations in China and other regions worldwide and studied the potential factors influencing wet and litterfall deposition fluxes of $\mathrm{Hg}$.

\section{Materials and methods}

\subsection{Site description}

Precipitation samples were collected at six rural sites and one urban site across a broad geographic area in mainland China: Mt. Changbai (MCB, $128.112^{\circ} \mathrm{E}$, $42.403^{\circ} \mathrm{N}, 736 \mathrm{~m}$ above sea level), Mt. Damei (MDM, $121.565^{\circ} \mathrm{E}, 29.632^{\circ} \mathrm{N}, 550 \mathrm{~m}$ a.s.1.), Mt. Leigong (MLG, $108.203^{\circ} \mathrm{E}, 26.387^{\circ} \mathrm{N}, 2176 \mathrm{~m}$ a.s.l.), Mt. Ailao (MAL, $101.107^{\circ} \mathrm{E}, \quad 24.533^{\circ} \mathrm{N}, 2450 \mathrm{~m}$ a.s.1.), Mt. Waliguan (MWLG, $100.898^{\circ} \mathrm{E}, 36.287^{\circ} \mathrm{N}, 3816 \mathrm{~m}$ a.s.1.), Bayinbuluk (BYBLK, $83.717^{\circ} \mathrm{E}, 42.893^{\circ} \mathrm{N}, 2500 \mathrm{~m}$ a.s.1.), and Guiyang (GY, $106.724^{\circ} \mathrm{E}, 26.573^{\circ} \mathrm{N}, 1041 \mathrm{~m}$ a.s.1.) (Fig. 1). Four sites (i.e., MCB, MDM, MLG, and MAL) are rural upland forest sites, two sites (i.e., MWLG and BYBLK) are alpine grassland sites and the remainder (i.e., GY) is an urban site (Table 1).

The MCB site is located in a temperate broadleaf and Korean pine mixed forest on the northern slope of Mt. Changbai, northeastern China, which is one of the largest national forest reserves in China and covers an area of $\sim 1965 \mathrm{~km}^{2}$. The forest is dominated by tree species of Pinus koraiensis, Fraxinus mandshurica, Tilia amurensis, Acer mono and Quercus mongolica (Dai et al., 2011). There are no nearby sources at the MCB site and the predominant wind directions are from southwest to northwest, which could carry air pollutants from regional industrial and urbanized centers and northern China by long-range atmospheric transport (Fu et al., 2012b).

The MDM site is located at the summit of Mt. Damei in the eastern Yangtze River Delta, eastern China, and about $15 \mathrm{~km}$ away from the East China Sea coast. This site is surrounded by a shrub (Styrax faberi, Lithocarpus glaber, and Indocalamus tessellates), broadleaf (Quercus fabri, Liquidambar formosana, and Platycarya Strobilacea) and conifer (Pinus massoniana) mixed forest. The Yangtze River Delta is one of the largest atmospheric $\mathrm{Hg}$ source regions in China (L. Zhang et al., 2015). There are no large point sources within $5 \mathrm{~km}$ of the sampling site. The predominant wind direction during the wet season is from the east and the site mainly receives clean marine air masses. During the dry season, the predominant wind direction changes to from the northwest, which enhances the transport of air pollutants from northern and eastern China to the sampling site (Yu et al., 2015).

The MLG site is located on top of an isolated peak (elevated approximately $1000 \mathrm{~m}$ relative to the surrounding terrain) of the Miaoling mountain range, southwestern China. The sampling site is surrounded by an upland shrub (Rhododendron) and deciduous broadleaf mixed forest (Cinnamomum, Acer Linn., Chaenomeles, Sinarundinaria Nakai). It is isolated from industrial sources and populated regions and frequently receives free tropospheric air from central China plain regions and the South China Sea (SCS) (Fu et al., 2010a). The MLG site is also influenced by boundary layer 
Table 1. Sampling site information, volume-weighted mean (VWM) concentrations and annual wet deposition fluxes of Hg in precipitation at remote sites and an urban site of China.

\begin{tabular}{|c|c|c|c|c|c|c|c|c|c|}
\hline Site name & Site ID & Long $\left(^{\circ}\right)$ & Lat $\left({ }^{\circ}\right)$ & $\begin{array}{l}\text { Elevation } \\
\text { (m a.s.l) }\end{array}$ & Site category & Data coverage & $\begin{array}{l}\text { Annual } \\
\text { rainfall } \\
(\mathrm{mm})\end{array}$ & $\begin{array}{l}\text { VWM Hg } \\
\text { concentration } \\
\left(\mathrm{ngL}^{-1}\right)\end{array}$ & $\begin{array}{l}\text { Annual wet } \mathrm{Hg} \\
\text { deposition } \\
\text { flux }\left(\mu \mathrm{g} \mathrm{m}^{-2}\right)\end{array}$ \\
\hline Mt. Changbai & MCB & 128.112 & 42.403 & 736 & Rural forest & Aug 2011-Aug 2014 & 751 & $7.4 \pm 6.1(n=68)$ & $5.6 \pm 4.6$ \\
\hline Mt. Damei & MDM & 121.565 & 29.632 & 550 & Rural forest & Aug 2012-Aug 2014 & 1621 & $3.7 \pm 2.8(n=63)$ & $6.0 \pm 4.6$ \\
\hline Mt. Leigong & MLG & 108.203 & 26.387 & 2176 & Rural forest & May 2008-May 2009 & 1533 & $4.0 \pm 2.8(n=31)$ & $6.1 \pm 4.2$ \\
\hline Mt. Ailao & MAL & 101.107 & 24.533 & 2450 & Rural forest & May 2011-May 2014 & 1931 & $3.7 \pm 2.4(n=103)$ & $7.2 \pm 4.7$ \\
\hline Mt. Waliguan & MWLG & 100.898 & 36.287 & 3816 & Rural grassland & May 2012-Aug 2014 & 290 & $6.9 \pm 8.6(n=65)$ & $2.0 \pm 2.4$ \\
\hline Bayinbuluk & BYBLK & 83.717 & 42.893 & 2500 & Rural grassland & Dec 2013-Dec 2014 & 266 & $7.7 \pm 6.0(n=36)$ & $2.0 \pm 1.6$ \\
\hline Guiyang & GY & 106.724 & 26.573 & 1041 & Urban & Sep 2012-Aug 2013 & 1057 & $11.9 \pm 6.1(n=29)$ & $12.6 \pm 6.5$ \\
\hline
\end{tabular}

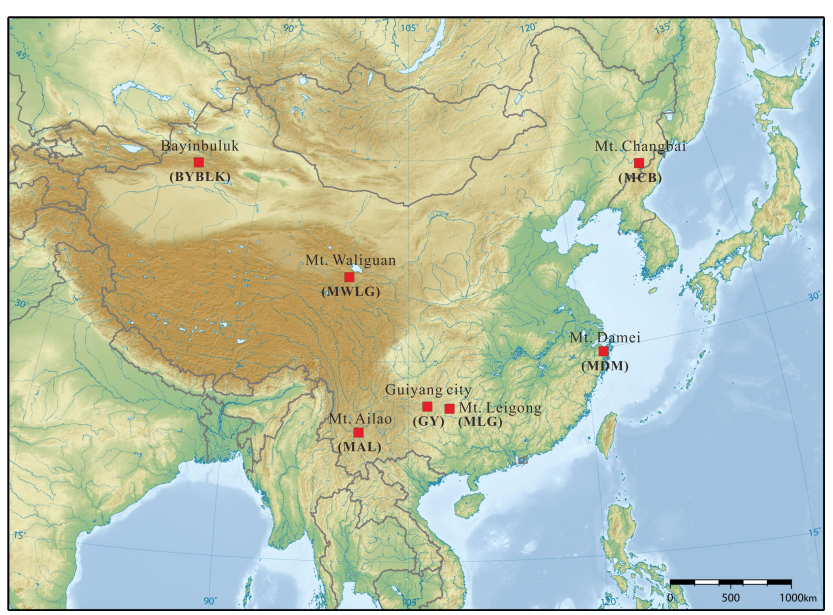

Figure 1. Locations of the sampling sites in this study.

air transported by plain-to-mountain winds from southwestern China during daytime.

The MAL site is located at a summit of the northern edge of the Ailao Mountain National Nature Reserve in central Yunnan province, southwestern China. The reserve has an area of $677 \mathrm{~km}^{2}$ and is predominantly $(>80 \%)$ covered by evergreen broadleaf primary forests. Canopy species mainly include Castanopsis wattii, Lithocarpus xylocarpus, Schima noronhae, L. jingdongensis, and Hartia sinensi (Yuan et al., 2009). The MAL site is located $180 \mathrm{~km}$ southwest of Kuming, the capital of Yunnan province, and $200 \mathrm{~km}$ north of the Indochinese Peninsula. This site is frequently influenced by long-range transport of $\mathrm{Hg}$ released from anthropogenic sources and biomass burning in southwestern China, the Indochinese Peninsula, and South Asia (Zhang et al., 2016).

The MWLG site is situated at the summit of Mt. Waliguan at the edge of northeastern part of the Qinghai-Xizang (Tibetan) Plateau. The surrounding area is mainly dominated by naturally preserved upland grasslands and arid/semi-arid lands and there are no nearby sources. The potential source regions are industrial and urbanized centers in northwestern China and northern India (Fu et al., 2012a).
The BYNLK site is located in the Bayinbuluk upland grassland in the southern Tianshan mountains, Xinjiang Uygur Autonomous Region, central Asia, and with a total area of $\sim 23000 \mathrm{~km}^{2}$. The surrounding area is rural and the population density is generally lower than 1 person $\mathrm{km}^{-2}$.

The GY site is located in the downtown of Guiyang, the capital city of Guizhou province, southwestern China, with a population of $\sim 4.5$ million. Guiyang is heavily polluted with respect to atmospheric $\mathrm{Hg}$ due to significant industrial emissions (Fu et al., 2011). Surrounding areas of the sampling site are mixed residential and commercial.

\subsection{Precipitation collection and analysis}

Precipitation samples were collected in 2011-2014 at MCB and MAL, 2012-2014 at MDM and MWLG, 2013-2014 at BYBLK, 2012-2013 at GY, and 2008-2009 at MLG. Wet-only precipitation samples were collected at all the studied sites using wet-only automatic precipitation collectors (HHG9-ZJC-III, Beijing Midwest Great Technology Co. Ltd., Beijing, China) with the exception of the MLG site. Wet-only precipitation samples at the MLG site were collected using a manual method described in Fu et al. (2010a). The HHG9-ZJC-III sampler consists of a $25 \mathrm{~cm}$ diameter, borosilicate glass bucket (volume: $15 \mathrm{~L}$ ) for precipitation collection and a moisture sensor that could move a cover from and back to the bucket at the onset and the end of a precipitation event using a mechanical arm, respectively (Price et al., 2008). The cover consists of a foam pad encased in plastic wrap and forces a tight seal over the borosilicate glass bucket to prevent evaporation of the sample. The borosilicate glass bucket was baked for $1 \mathrm{~h}$ in a muffle furnace at a temperature of $500^{\circ} \mathrm{C}$ before field sampling and rigorously rinsed by Milli-Q water before each of the new sampling cycles during the field sampling, and this aimed to avoid possible contamination during the collection of precipitation $\mathrm{Hg}$ (Burke et al., 1995). Immediately after a precipitation event, the precipitation sample was transferred carefully to a rigorously acidcleaned Teflon sample bottle (volume: $250 \mathrm{~mL}$ ). Extra samples during heavy precipitation events (e.g., accumulative precipitation depth of $>6 \mathrm{~mm}$ ) were used for anion and trace element analysis or abandoned in the field. We caution that, 
due to the adsorptive behavior of $\mathrm{Hg}$ to the wall of borosilicate glass bucket, $\mathrm{Hg}$ in precipitation might be lost to the bucket during the transfer processes, which consequently resulted in an underestimation of $\mathrm{Hg}$ concentrations in precipitation. However, the artifact during transferring of precipitation is expected to be low because pervious studies observed minor adsorption of $\mathrm{Hg}$ to the clean Teflon and borosilicate glass surface (Vermette et al., 1995; Landis and Keeler, 1997). In the winter at several sampling sites, i.e., MCB, MWLG, and BYBLK, surface fresh snow was collected from the upper $1 \mathrm{~cm}$ of the snowpack at open-air sites using a precleaned Teflon scoop. Snow samples were collected immediately after snow events. The snow samples were transferred carefully to a thoroughly acid-cleaned Teflon sample bottle (volume: $400 \mathrm{~mL}$ ) and remained sealed at a room temperature of $10-20^{\circ} \mathrm{C}$ in the dark to melt snow. After the completion of field sampling, trace metal grade $\mathrm{HCl}$ (to $5 \%$ of total sample volume) was added into the Teflon bottles with rain and snow samples and each sample was individually sealed into three successive polyethylene bags and kept in a refrigerator at $4{ }^{\circ} \mathrm{C}$ until $\mathrm{Hg}$ analysis. To ensure clean operation, polyethylene gloves were worn throughout the sample collection period.

$\mathrm{Hg}$ concentrations in precipitation were analyzed using US EPA Method 1631 (USEPA, 2002). Briefly, Hg in precipitation was purged from solution in a $\mathrm{Hg}$-free nitrogen stream and concentrated onto a gold-coated sand trap after oxidation by $\mathrm{BrCl}$ followed by addition of $\mathrm{NH}_{2} \mathrm{OH} \cdot \mathrm{HCl}$ to discharge the excess $\mathrm{BrCl}$ and reduction of divalent $\mathrm{Hg}$ by $\mathrm{SnCl}_{2}$ to $\mathrm{Hg}^{0}$. The trapped $\mathrm{Hg}$ is then thermally desorbed from the gold trap into an inert gas stream and quantified using a dual amalgamation technique followed by cold-vapor atomic fluorescence spectrometry (CVAFS) (USEPA, 2002). The data quality was controlled using laboratory blank tests $\left(<0.3 \mathrm{ng} \mathrm{L}^{-1}\right)$, field blank tests ( $\mathrm{Hg}$ conc. $\left.=0.46 \pm 0.51 \mathrm{ng} \mathrm{L}^{-1}, 1 \mathrm{SD}, n=21\right)$, and the Interlaboratory Comparison Program initiated by the U.S. Geological Survey (USGS, https://bqs.usgs.gov/PCQA/Interlaboratory_ Comparison/). The measured $\mathrm{Hg}$ values of the standard reference samples prepared by the USGS during 2012-2014 were overall within the quality control acceptance criteria $(62 \%$ and $90 \%$ ) of measured values were within the 10 and $20 \%$ of the most probable values (MPV, the mean results submitted by all the laboratory participants, respectively) and showed a mean difference of $0.47 \pm 1.55 \mathrm{ng} \mathrm{L}^{-1}(1 \mathrm{SD}, n=50)$ in $\mathrm{Hg}$ concentrations between the measured values and MPV.

\subsection{Collection and analysis of litterfall samples}

Litterfall samples were collected using litterfall collectors $\left(0.25 \mathrm{~m}^{2}\right.$ at MLG and $1.0 \mathrm{~m}^{2}$ at MCB, MDM, and MAL) at the sampling sites (St. Louis et al., 2001; Fisher and Wolfe, 2012; Risch et al., 2012). The collectors were constructed using an untreated wood frame and a Nylon net bottom with a pore size of $1.0 \mathrm{~mm} \times 1.0 \mathrm{~mm}$. At the MCB, MDM,
MLG, and MAL sites, four, four, three, and eight collectors were deployed, respectively, which were located under the predominant tree species at the study sites. The litterfall collectors were elevated by approximately $20-40 \mathrm{~cm}$ above the ground surfaces. Collections of litterfall at the MDM, MLG, and MAL sites were conducted throughout a fullyear sampling campaign (Table 2). Collections of litterfall at the MCB site were conducted from September to October 2013, during which the accumulative litterfall biomass fluxes in the four collectors ranged from 214 to $355 \mathrm{~g} \mathrm{~m}^{-2}$ (mean: $281 \pm 59 \mathrm{~g} \mathrm{~m}^{-2}, 1 \mathrm{SD}, n=4$ ), corresponding to approximately $58 \%$ of the annual litterfall mass flux at the sampling site (Zhou et al., 2014). We therefore assume that the measured $\mathrm{Hg}$ concentrations in litterfall at the MCB site were representative of the annual means. Litterfall samples were collected monthly, packed into paper bags, and air-dried in a clean environment (i.e., low atmospheric TGM concentration $\left(<3 \mathrm{ng} \mathrm{m}^{-3}\right)$, relatively dry air condition and isolated from precipitation) near the sampling sites. Litterfall samples were milled using a pre-cleaned food blender and stored in the laboratory until $\mathrm{Hg}$ analysis. Polyethylene gloves were worn throughout the sample collections and grinding period and the blenders were cleaned with Mili-Q water and ethanol between samples to prevent potential contaminations.

$\mathrm{Hg}$ concentrations in litterfall samples were determined using a Lumex RA-915 b multifunctional mercury analyzer (Lumex Ltd., Russia) equipped with a pyrolysis attachment. The Lumex RA-915 b analyzer was routinely calibrated and the QA/QC of the measurements of litterfall samples were controlled by procedural blanks, certificated reference materials (GBW10020, $150 \mathrm{ng} \mathrm{g}^{-1}$ ), and duplicated analyses. The recoveries of certified standards ranged from 88 to $112 \%$ (mean: $98 \pm 5 \%, 1 \mathrm{SD}, n=60$ ) for plant samples. All samples were measured in duplicates and the mean concentrations were adopted in this study.

\subsection{Deposition fluxes of $\mathrm{Hg}$ in precipitation and litterfall}

The volume-weighted mean (VWM) $\mathrm{Hg}$ concentration at each sampling site was calculated using Eq. (1):

$\mathrm{VWM}=\frac{\sum_{i}^{n} \mathrm{Hg}_{i} \times \mathrm{PD}_{i}}{\sum_{i}^{n} \mathrm{PD}_{i}}$

where VWM is the volume-weighted mean of precipitation $\mathrm{Hg}$ concentrations in $\mathrm{ng} \mathrm{L}^{-1}$, and $\mathrm{Hg}_{i}$ and $\mathrm{PD}_{i}$ are the $\mathrm{Hg}$ concentration $\left(\mathrm{ng} \mathrm{L}^{-1}\right)$ and precipitation depth $(\mathrm{mm})$ of a single precipitation event $i$, respectively.

Annual wet deposition flux of $\mathrm{Hg}$ at each sampling site was estimated using the VWM Hg concentration calculated from all samples and the mean annual precipitation depth. Mean litterfall deposition flux of $\mathrm{Hg}$ at each sampling site was calculated by averaging the litterfall $\mathrm{Hg}$ fluxes obtained for all litterfall collectors, which were calculated by multi- 
Table 2. Sampling site information, concentrations and annual litterfall deposition fluxes of $\mathrm{Hg}$ in litterfall at remote forest sites of China.

\begin{tabular}{|c|c|c|c|c|c|c|}
\hline Site name & Site ID & Sampling period & Collector & $\begin{array}{l}\text { Concentration } \\
\left(n g^{-1}\right)\end{array}$ & $\begin{array}{l}\text { Annual litterfall } \\
\text { mass flux }\left(\mathrm{g} \mathrm{m}^{-2}\right)\end{array}$ & $\begin{array}{l}\text { Annual litterfall } \\
\mathrm{Hg} \text { flux }\left(\mu \mathrm{g} \mathrm{m}^{-2}\right)\end{array}$ \\
\hline \multirow[t]{5}{*}{ Mt. Changbai } & MCB & Sep-Oct 2013 & MCB-1 & 74.6 & $486^{*}$ & 36.2 \\
\hline & & & MCB-2 & 41.4 & $486^{*}$ & 20.1 \\
\hline & & & MCB-3 & 31.1 & $486^{*}$ & 15.1 \\
\hline & & & MCB-4 & 40.9 & $486^{*}$ & 19.9 \\
\hline & & & Average \pm SD & $47.0 \pm 19.0$ & 486 & $22.8 \pm 9.2$ \\
\hline \multirow[t]{5}{*}{ Mt. Damei } & MDM & Aug 2012-Jul 2013 & MDM-1 & 42.8 & 381 & 16.3 \\
\hline & & & MDM-2 & 52. & 614 & 31.9 \\
\hline & & & MDM-3 & 52.3 & 557 & 29.1 \\
\hline & & & MDM-4 & 42.0 & 354 & 14.9 \\
\hline & & & Average \pm SD & $42.3 \pm 5.6$ & $476 \pm 128$ & $23.1 \pm 8.7$ \\
\hline \multirow[t]{4}{*}{ Mt. Leigong } & MLG & May 2008-Apr 2009 & MLG-1 & 57.2 & 308 & 17.6 \\
\hline & & & MLG-2 & 106.2 & 287 & 30.5 \\
\hline & & & MLG-3 & 109.8 & 642 & 70.4 \\
\hline & & & Average \pm SD & $91.1 \pm 29.4$ & $412 \pm 199$ & $39.5 \pm 275$ \\
\hline \multirow[t]{9}{*}{ Mt. Ailao } & MAL & Jun 2012-May 2013 & MAL-1 & 58.0 & 1131 & 65.6 \\
\hline & & & MAL-2 & 55.8 & 1053 & 58.8 \\
\hline & & & MAL-3 & 62.7 & 948 & 59.4 \\
\hline & & & MAL-4 & 48.4 & 1710 & 82.8 \\
\hline & & & MAL-5 & 60.6 & 1001 & 60.7 \\
\hline & & & MAL-6 & 53.7 & 760 & 40.8 \\
\hline & & & MAL-7 & 59.0 & 1232 & 72.7 \\
\hline & & & MAL-8 & 56.8 & 1080 & 61.3 \\
\hline & & & Average \pm SD & $56.9 \pm 4.4$ & $1114 \pm 278$ & $62.8 \pm 12.1$ \\
\hline
\end{tabular}

*Annual litterfall mass flux: values were cited from Zhou et al. (2014).

plying the $\mathrm{Hg}$ concentration in litters by the corresponding annual litterfall biomass.

\section{Results and discussion}

\subsection{Precipitation $\mathrm{Hg}$ concentrations and deposition fluxes}

Concentrations of $\mathrm{Hg}$ in precipitation and corresponding precipitation depth are presented in Fig. 2. A large variation in precipitation $\mathrm{Hg}$ concentrations was observed at all sampling sites, with the maximum concentrations up to an order of magnitude higher than the minimum concentrations. The VWM Hg concentrations in precipitation at the remote sites varied from 3.7 to $7.7 \mathrm{ng} \mathrm{L}^{-1}$ (mean: $5.6 \pm 2.0 \mathrm{ng} \mathrm{L}^{-1}$, Table 1), with the highest VWM Hg concentration observed at the BYBLK site and the lowest at the MAL and MDM sites. The VWM Hg concentration in precipitation at the urban site of GY was $11.9 \pm 6.1 \mathrm{ng} \mathrm{L}^{-1}$, which was 1.5 to 3.2 times higher than the values at remote sites (Table 1). We acknowledge that, due to the lack of long-term simultaneous observations, the variation in VWM Hg concentrations in precipitation among the sampling sites may have uncertainties. In the present study, precipitation samples at the urban and rural sites were collected throughout 1 to 3 years, and there might exist interannual variations in VWM Hg concentrations at each sampling site. For example, the maximum annual VWM $\mathrm{Hg}$ concentration $\left(5.1 \mathrm{ng} \mathrm{L}^{-1}\right)$ at MAL was observed during June 2013-May 2014, which was approximately 1.8 times higher than that $\left(2.9 \mathrm{ng} \mathrm{L}^{-1}\right)$ during June 2011-May 2012. At MCB, annual VWM Hg concentrations were highest $\left(8.1 \mathrm{ng} \mathrm{L}^{-1}\right)$ during August 2012-July 2013 and lowest (6.0 $\mathrm{ng} \mathrm{L}^{-1}$ ) during August 2013-July 2014.

VWM $\mathrm{Hg}$ concentrations in precipitation at all sites showed a clear season trend, with lower concentrations in the summer wet season and higher concentrations in the winter dry season (Fig. 3). This pattern is consistent with previous observations in rural and urban areas of China (Huang et al., 2012, 2013; Ma et al., 2016). Higher Hg concentrations in precipitation during the winter dry season were potentially due to elevated wintertime atmospheric PBM concentrations in China (Fu et al., 2008; Zhang et al., 2013; Xu et al., 2014; Zhu et al., 2014), which could be incorporated into wet deposition via scavenging processes below cloud. Lower VWM Hg concentrations in precipitation during the summer wet season were mostly associated with higher precipitation amounts at the sampling sites, suggesting increasing amounts of precipitation would dilute the $\mathrm{Hg}$ concentra- 

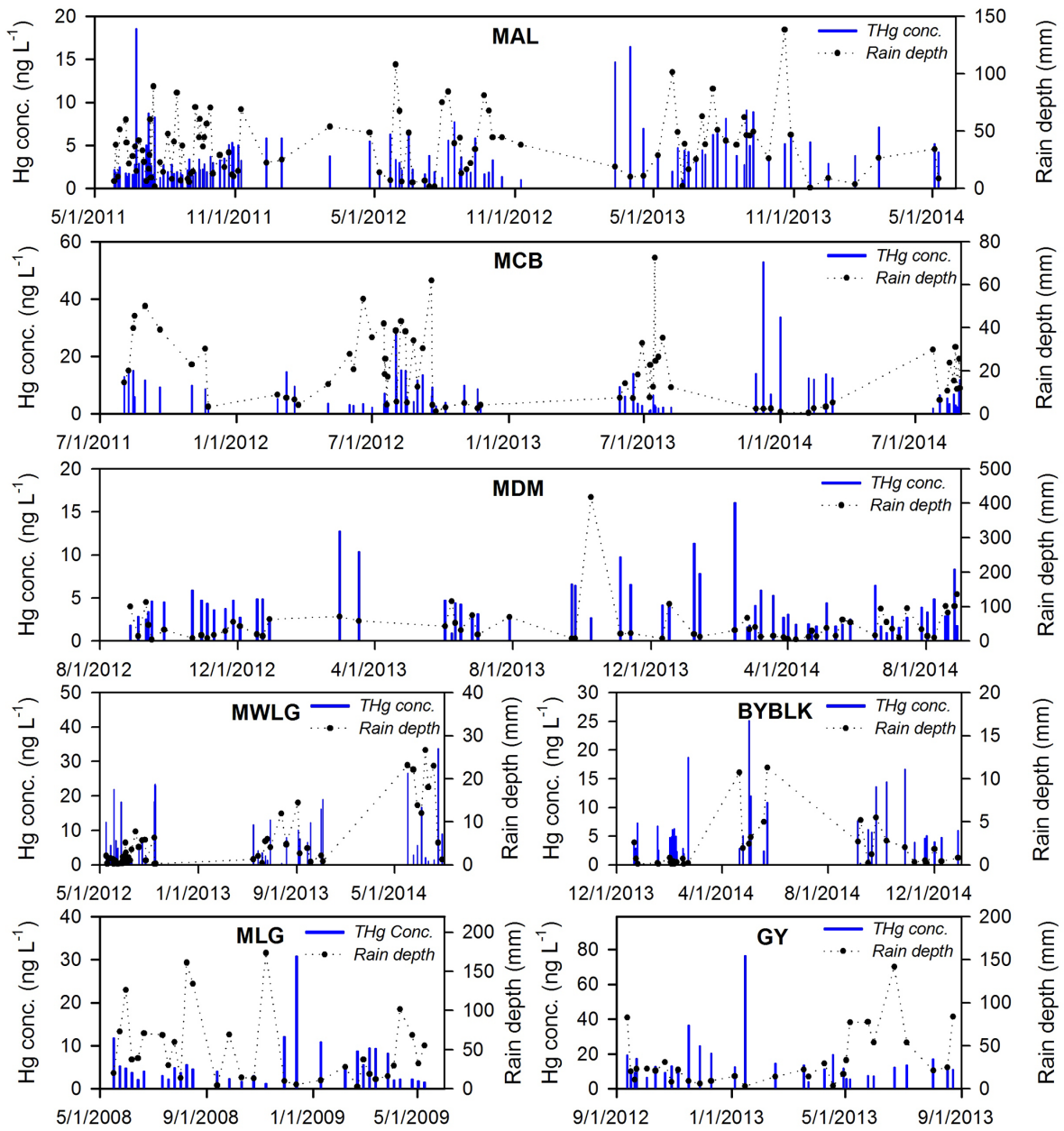

Figure 2. Mercury concentration and rain depth in a single precipitation event at Mt. Ailao (MAL), Mt. Changbai (MCB), Mt. Damei (MDM), Mt. Waliguan (MWLG), Bayinbuluk (BYBLK), Mt. Leigong (MLG) and urban Guiyang (GY) in this study.

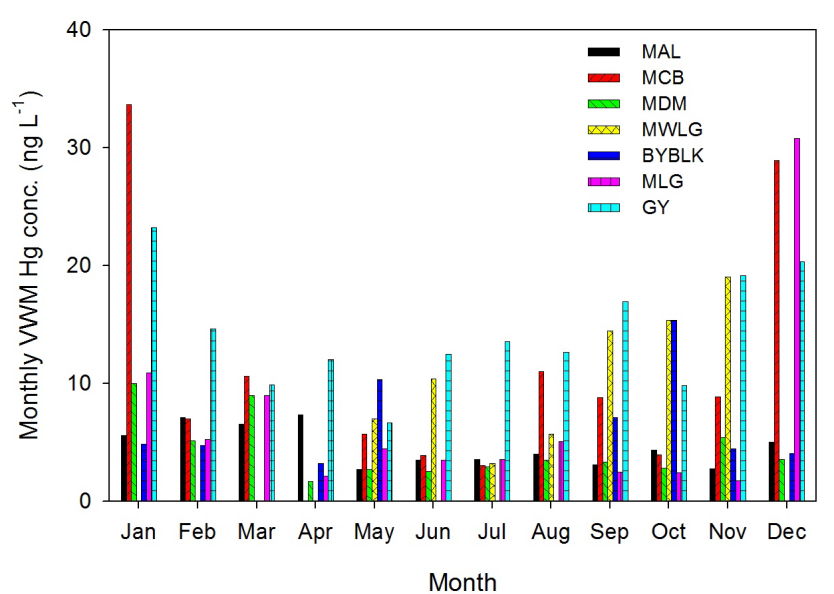

Figure 3. Monthly variations in volume-weighted mean (VWM) Hg concentrations at rural and urban sites in China. tions in samples that were scavenged from the boundary layer during the onset of the precipitation (Gratz et al., 2009; Yuan et al., 2015).

Annual fluxes of $\mathrm{Hg}$ in precipitation at the sampling sites varied from 2.0 to $12.6 \mu \mathrm{g} \mathrm{m}^{-2} \mathrm{yr}^{-1}$ (mean: $5.9 \pm 3.6 \mu \mathrm{g} \mathrm{m}^{-2} \mathrm{yr}^{-1}$, Table 1). Wet deposition fluxes showed a clear urban-rural difference, with the annual deposition flux at the urban site of GY elevated by a factor of 1.8 to 6.3 compared to the values at rural sites. This could be partly due to the elevated VWM Hg concentration in precipitation at the GY site. Wet deposition fluxes at rural sites also showed a clear regional difference. The annual wet deposition fluxes of $\mathrm{Hg}$ in the subtropical zones in southwestern and eastern China (i.e., MAL, MLG, and MDM) were relatively higher (by a factor of 1.1 to 1.3 ) than that at the MCB site in the temperate zone in northeastern China, and much higher (by a factor of 3 to 3.6) than that at the MWLG and BYBLK sites, which were located in the arid/semi-arid zones in northwestern China. This regional variation could not be explained by the difference of VWM $\mathrm{Hg}$ concentrations in 
precipitation because the correlation between annual wet deposition fluxes of $\mathrm{Hg}$ and VWM $\mathrm{Hg}$ concentrations in precipitation is not significant $(p>0.05)$. Instead, annual wet deposition fluxes of $\mathrm{Hg}$ were positively correlated with annual precipitation depth at the remote sites $\left(r^{2}=0.86, p<0.01\right)$. This suggests that precipitation depth had a greater influence on the regional variation of wet deposition fluxes of $\mathrm{Hg}$ at remote sites of China than VWM Hg concentrations, which is in agreement with previous studies in North America (Risch et al., 2012; L. Zhang et al., 2012).

The VWM Hg concentrations in precipitation at the remote sites of this study were overall consistent with previous observations in China (Fig. 4). For example, VWM Hg concentrations in precipitation and wet deposition fluxes of $\mathrm{Hg}$ at the Nam Co and SET stations of the Tibetan Plateau and in Mt. Simian, southwestern China, ranged from 4.0 to $10.9 \mathrm{ng} \mathrm{L}^{-1}$ and from 1.8 to $15.4 \mu \mathrm{g} \mathrm{m}^{-2} \mathrm{yr}^{-1}$, respectively (Huang et al., 2012, 2015; Ma et al., 2016). However, the VWM Hg concentration at the GY site was 1.0-4.4 times lower than the levels (12.3-52.9 $\left.\mathrm{ng} \mathrm{L}^{-1}\right)$ observed in other urban areas of China, and the wet deposition fluxes of $\mathrm{Hg}$ at the GY site were consequently lower than those (14.0$56.5 \mu \mathrm{g} \mathrm{m}^{-2} \mathrm{yr}^{-1}$ ) in the urban areas of China, with the exception of the flux observed in Lhasa of the Tibetan Plateau (flux: $8.2 \mu \mathrm{g} \mathrm{m}^{-2} \mathrm{yr}^{-1}$ ) (Wang et al., 2009, 2012; Huang et al., 2013; Xu et al., 2014; Zhu et al., 2014).

\subsection{Litterfall Hg concentrations and deposition fluxes}

Average $\mathrm{Hg}$ concentrations in litterfall at the MCB, MDM, MLG, and MAL sites were $47.0 \pm 19.0,42.3 \pm 5.6$, $91.1 \pm 29.4$, and $56.9 \pm 4.4 \mathrm{ng} \mathrm{g}^{-1}$, respectively (mean: $59.3 \pm 22.0 \mathrm{ng} \mathrm{g}^{-1}$, Table 2). Concentrations of $\mathrm{Hg}$ in litterfall could be affected by many factors, including atmospheric $\mathrm{Hg}$ concentrations, tree species, a "leaf maintenance" period, and environmental factors (Lindberg and Stratton, 1998; Frescholtz et al., 2003; Ericksen and Gustin, 2004; Millhollen et al., 2006; Poissant et al., 2008). The variation in litterfall $\mathrm{Hg}$ concentrations observed in different collectors (corresponding to sampling of different tree species) at each sampling site was insignificant ( $p$ values for all $>0.05$, Table 2). Annual mean atmospheric TGM at the MCB, MDM, MLG, and MAL sites was $1.73 \pm 0.48,3.31 \pm 1.44,2.80 \pm$ 1.51 , and $2.09 \pm 0.63 \mathrm{ng} \mathrm{m}^{-3}$ (Fu et al., 2015b), respectively, which was not significantly correlated with the Hg concentrations in litterfall samples $(p=0.87)$. The lack of significant correlation might be partly attributed to the fact that mean atmospheric TGM concentration during the "leaf maintenance" period for each tree species was not entirely equal to the annual means of atmospheric TGM at the sampling sites because of its seasonal variations (Fu et al., 2015b). In addition, other factors, including tree species, a "leaf maintenance" period, and regional environmental factors, should also play a more important role in litterfall $\mathrm{Hg}$ concentrations. $\mathrm{Hg}$ concentrations in litterfall at the MDM site were

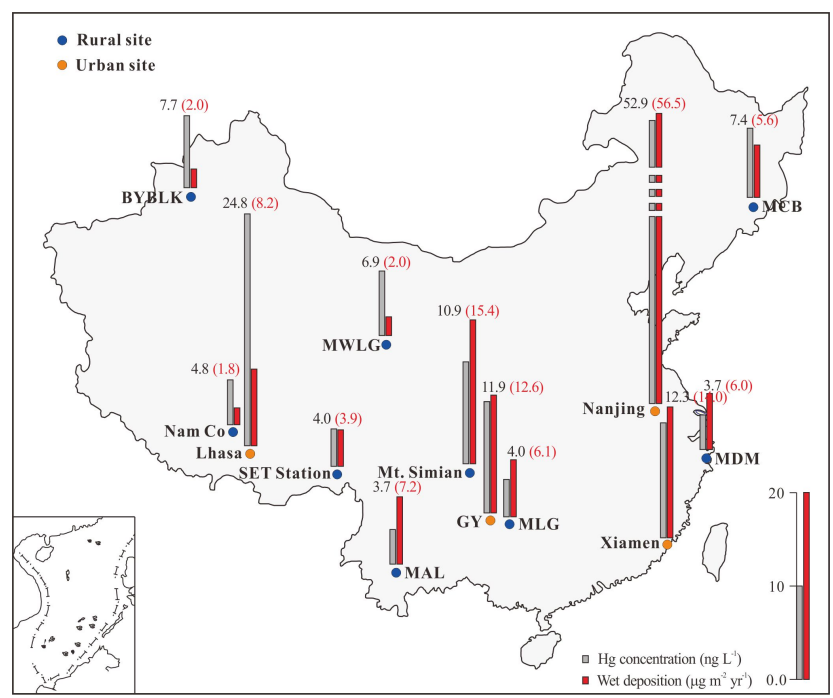

Figure 4. Annual VWM Hg concentrations in precipitation and wet deposition fluxes of $\mathrm{Hg}$ in this study and the literature (Huang et al., 2012, 2013, 2015; Xu et al., 2014; Zhu et al., 2014; Ma et al., 2016). Black and red values above the columns correspond to VWM concentration and wet deposition of $\mathrm{Hg}$, respectively.

found to increase from July to December (correlation slope $=7.0 \pm 0.7 \mathrm{ng} \mathrm{g}^{-1} \mathrm{mon}^{-1}, r^{2}=0.78, p<0.01$; litterfall was not collected during January-June due to little production of litterfall biomass). In contrast, significant monthly variation in $\mathrm{Hg}$ concentrations in litterfall samples at the MCB and MAL sites was not found ( $p$ values for both $>0.05$ ).

Annual fluxes of $\mathrm{Hg}$ through litterfall at the four sampling sites ranged from 22.8 to $62.8 \mu \mathrm{g} \mathrm{m}^{-2} \mathrm{yr}^{-1}$ (mean of $37.0 \mu \mathrm{g} \mathrm{m}^{-2} \mathrm{yr}^{-1}$, Table 2). The litterfall fluxes of $\mathrm{Hg}$ showed a clear regional distribution pattern, with the fluxes decreasing with latitude. The highest flux $\left(62.8 \mu \mathrm{g} \mathrm{m}^{-2} \mathrm{yr}^{-1}\right)$ was observed at the MAL site in the southern subtropical zone in southwestern China, followed by the MLG site (flux: $\left.39.5 \mu \mathrm{g} \mathrm{m}^{-2} \mathrm{yr}^{-1}\right)$ in the middle subtropical zone, the MDM

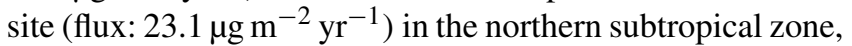
and the MCB site (flux: $23.1 \mu \mathrm{g} \mathrm{m}^{-2} \mathrm{yr}^{-1}$ ) in the middle temperate zone (Zheng et al., 2010). The relatively higher litterfall flux of $\mathrm{Hg}$ at the MAL and MLG sites could be explained by either higher annual biomass of litterfall or higher $\mathrm{Hg}$ concentrations in litterfall samples (Table 2). Deposition fluxes of $\mathrm{Hg}$ through litterfall in this study were comparable to those (35.5-42.9 $\mathrm{g} \mathrm{m}^{-2} \mathrm{yr}^{-1}$ ) measured in Mt. Gongga and Mt. Simian, southwestern China (Fu et al., 2010b; Ma et al., 2016), but substantially lower than that $\left(220 \mu \mathrm{g} \mathrm{m}^{-2} \mathrm{yr}^{-1}\right)$ measured at Tieshanping, which was close to Chongqing, southwestern China (Wang et al., 2009). 


\subsection{Relative contribution of wet and litterfall deposition to total $\mathrm{Hg}$ deposition in forests}

Ratios of annual mean litterfall deposition flux to annual wet deposition flux of $\mathrm{Hg}$ at the four sampling sites ranged from 3.9 to 8.7 (mean: $5.8 \pm 2.3$ ). The ratios were overall consistent with the previous observations (2.8 to 7.6) in China (Wang et al., 2009; Fu et al., 2010b; Ma et al., 2016). On the other hand, the observed ratios in China were much greater than those observed in North America and Europe. Rich et al. (2012) collected litterfall at 23 remote sites in the eastern USA and found that the mean ratio of litterfall $\mathrm{Hg}$ deposition to $\mathrm{Hg}$ wet deposition was 1.3 (ranged from 0.4 to 2.6), which was 3.0 to 6.7 times lower compared to the ratios observed in China. In Europe, ratios of litterfall $\mathrm{Hg}$ deposition to wet $\mathrm{Hg}$ deposition were in the range of 0.4 to 2.6 (mean: $1.2 \pm 0.8$; $n=5$ ) (Iverfeldt, 1991; Munthe et al., 1995; Lee et al., 2000; Schwesig and Matzner, 2000).

$\mathrm{Hg}$ in litterfall biomass has been suggested to be mostly from uptake of atmospheric TGM, and therefore litterfall deposition could be a good indicator of TGM dry deposition to forest ecosystems (Frescholtz et al., 2003; Gustin, 2012; L. Zhang et al., 2012). In addition to litterfall and wet deposition, dry deposition of PBM and GOM to the forest floor and other surfaces could also contribute to the total $\mathrm{Hg}$ deposition to a forest. Given the measured atmospheric PBM and GOM concentrations (Fu et al., 2015b; Yu et al., 2015), the dry deposition fluxes of PBM and GOM at the MCB, MDM, and MAL sites were estimated to be 3.0, 9.6, and $2.3 \mu \mathrm{g} \mathrm{m}^{-2} \mathrm{yr}^{-1}$, respectively, using the average dry deposition velocities of PBM and GOM over forests modeled by L. Zhang et al. (2012). At the MLG site, annual dry deposition flux of PBM and GOM was estimated to be $4.4 \mu \mathrm{g} \mathrm{m}^{-2} \mathrm{yr}^{-1}$ using the comparison of precipitation and throughfall data collected side by side (St. Louis et al., 2001; Fu et al., 2010a; Gustin, 2012). The importance of litterfall in the total deposition of $\mathrm{Hg}$ has been highlighted by many previous studies (St. Louis et al., 2001; Lindberg et al., 2007; Risch et al., 2012; L. Zhang et al., 2012). In this study, we estimate that litterfall deposition represented 60 $87 \%$ (mean: $74.5 \pm 11.4 \%$ ) of total $\mathrm{Hg}$ deposition to the four studied forests, which were much higher compared to those (mean: $46.2 \pm 12.5 \%$ ) over rural forests in North America and Europe (Munthe et al., 1995; Rea et al., 1996; Grigal et al., 2000; Lee et al., 2000; St. Louis et al., 2001; L. Zhang et al., 2012), whereas the wet deposition played a minor role (mean: $13.9 \pm 3.5 \%$ ) in the total $\mathrm{Hg}$ deposition budget. Therefore, Hg deposition through litterfall played a predominant role in the total $\mathrm{Hg}$ deposition budget in forest ecosystems in China.
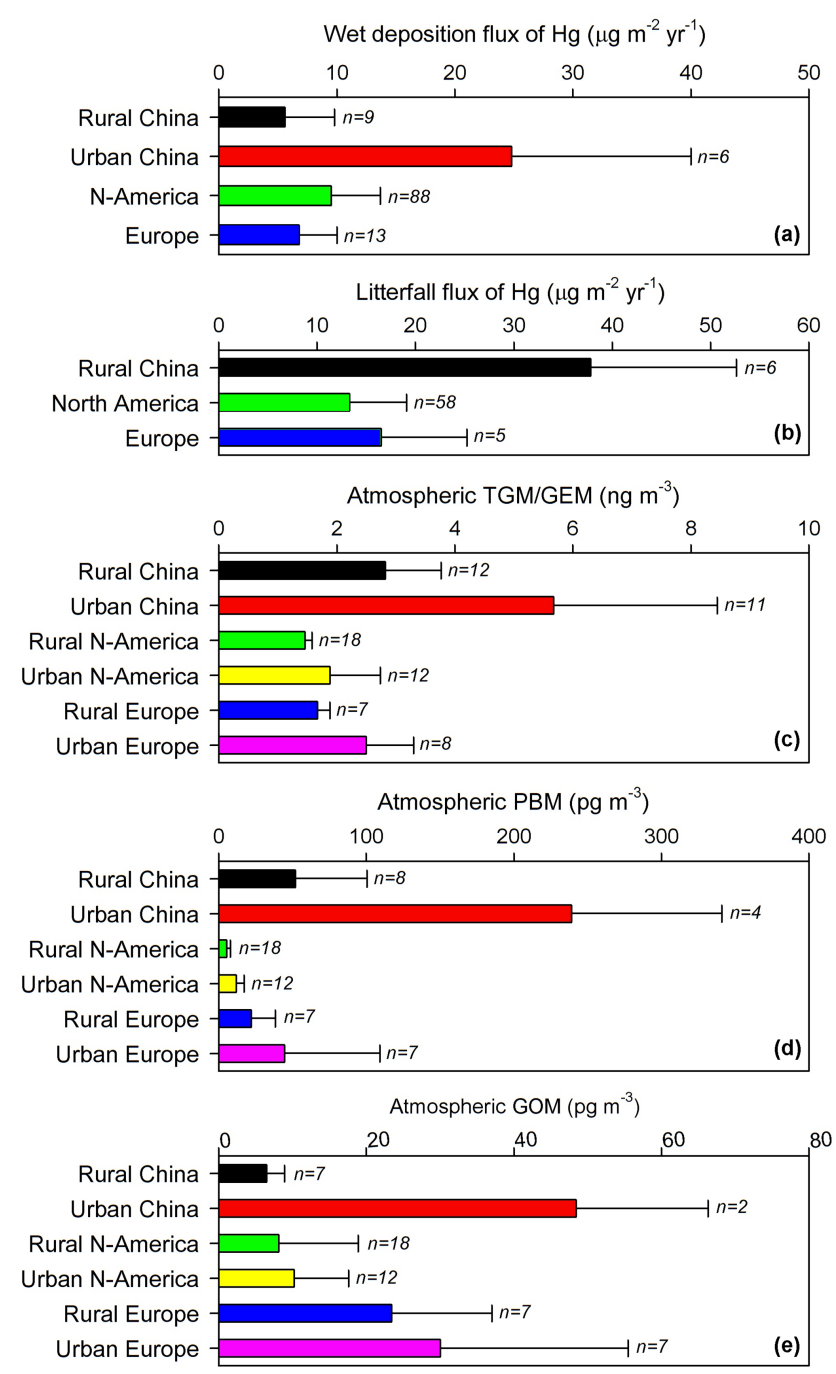

Figure 5. Comparison of (a) wet deposition flux of $\mathrm{Hg}$; (b) litterfall deposition of $\mathrm{Hg}$; (c) atmospheric total gaseous mercury (TGM)/gaseous elemental mercury (GEM) concentrations; (d) atmospheric particulate bound mercury (PBM) concentrations; and (e) atmospheric gaseous oxidized mercury (GOM) concentrations between China and North America and Europe. Note that atmospheric PBM in Europe is referred to as total particulate bound mercury and in the remaining regions is referred to as particulate bound mercury on particles with an aerodynamic diameter of $<2.5 \mu \mathrm{m}$. Data are from this study, the literature, and references therein (EMEP; Munthe et al., 1995, 2003; Lee et al., 2000; Schwesig and Matzner, 2000; St. Louis et al., 2001; Pirrone et al., 2003; Swartzendruber et al., 2006; Wang, 2006; Yatavelli et al., 2006; Demers et al., 2007; Lindberg et al., 2007; Valente et al., 2007; Bushey et al., 2008; Choi et al., 2008; Larssen et al., 2008; Li et al., 2008; Fain et al., 2009; Peterson et al., 2009; Prestbo and Gay, 2009; Song et al., 2009; Wang et al., 2009; Engle et al., 2010; Sprovieri et al., 2010; Liu et al., 2011; Fisher and Wolfe, 2012; Fu et al., 2012b; Juillerat et al., 2012; Risch et al., 2012; X. T. Zhang et al., 2012; Chen et al., 2013; Zhu et al., 2014; Fu et al., 2015b, 2016; Ma et al., 2016). 


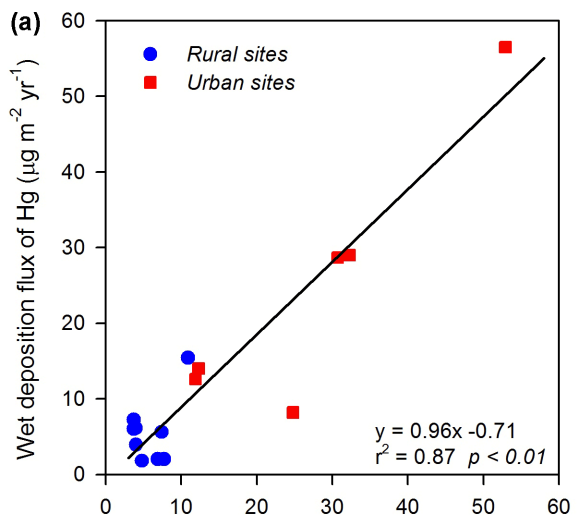

VWM Hg concentrations in precipitation $\left(\mathrm{ng} \mathrm{L}^{-1}\right)$

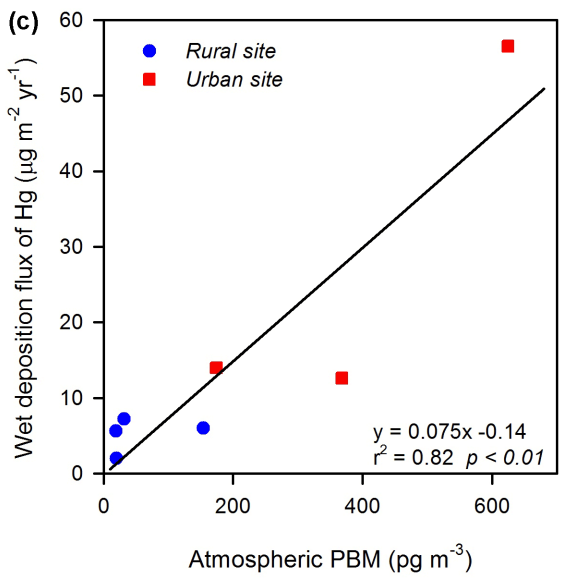

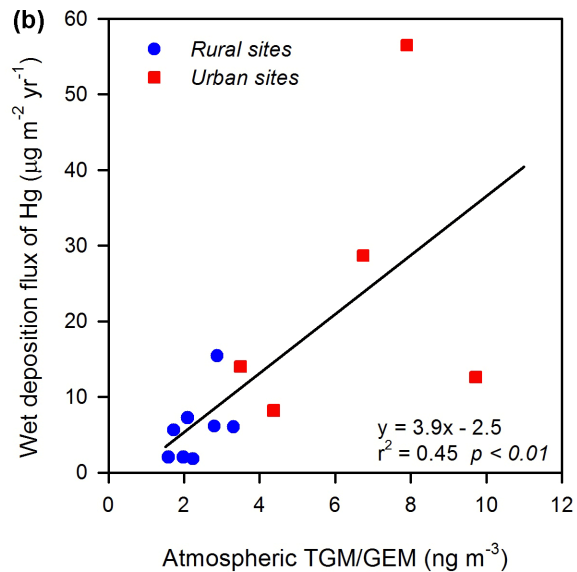

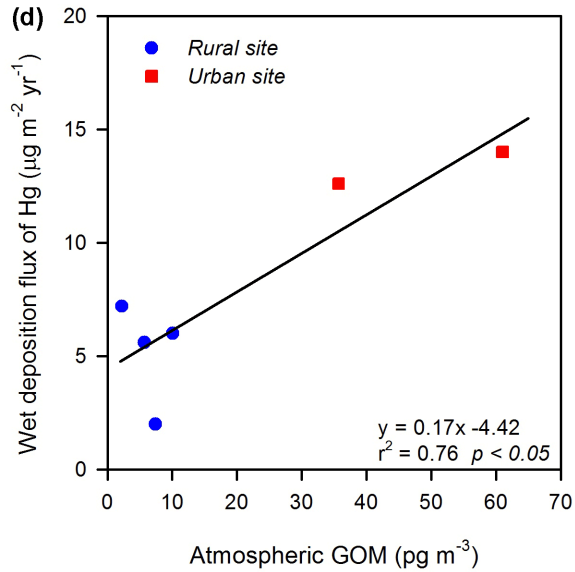

Figure 6. Correlations between wet deposition fluxes of $\mathrm{Hg}$ and (a) volume-weighted mean (VWM) $\mathrm{Hg}$ concentrations in precipitation, (b) atmospheric total gaseous mercury (TGM)/gaseous elemental mercury (GEM) concentrations, (c) atmospheric particulate bound mercury (PBM) concentrations, and (d) atmospheric gaseous oxidized mercury (GOM) concentrations in China. Data are from this study and the literature (Wang, 2006; Fu et al., 2011, 2015b; Huang et al., 2012; Wang et al., 2012; Zhu et al., 2012, 2014; Huang et al., 2013; Xu et al., 2014, 2015).

\subsection{Comparison with observations in other regions worldwide}

Figure 5 shows the comparison of wet deposition and litterfall fluxes of $\mathrm{Hg}$ as well as TGM/GEM, PBM, and GOM concentrations in China, North America, and Europe. The mean wet deposition flux of $\mathrm{Hg}$ at remote sites in China was $5.6 \pm 4.2 \mu \mathrm{g} \mathrm{m}^{-2} \mathrm{yr}^{-1}$ (Fig. 5a, data from this study and the literature, Huang et al., 2012, 2015; Ma et al., 2016), which is 4.4 times lower than the mean $\left(24.8 \pm 17.8 \mu \mathrm{g} \mathrm{m}^{-2} \mathrm{yr}^{-1}\right)$ at urban sites of China (Fig. 5a, data are from this study and the literature, Wang et al., 2009, 2012; Huang et al., 2013; Xu et al., 2014; Zhu et al., 2014). The mean wet deposition fluxes of $\mathrm{Hg}$ in North America and Europe were $9.5 \pm 4.2$ and $6.8 \pm 3.2 \mu \mathrm{g} \mathrm{m}^{-2} \mathrm{yr}^{-1}$ (Fig. 5a), respectively (EMEP; Prestbo and Gay, 2009). In contrast to the observations in China, the urban-rural variation in the wet deposition fluxes of $\mathrm{Hg}$ was insignificant in North America (L. Zhang et al., 2012).
The observations from this study and the literature suggested that wet deposition fluxes of $\mathrm{Hg}$ in urban areas of China were highly elevated (by a factor of 2.6 to 3.6) compared to North America and Europe. In China, wet deposition fluxes of $\mathrm{Hg}$ were significantly correlated with VWM Hg concentrations in precipitation $\left(r^{2}=0.87, p<0.01\right.$, Fig. 6a), whereas no significant correlation existed between wet deposition fluxes of $\mathrm{Hg}$ and annual precipitation depth $\left(r^{2}=\right.$ $0.02, p=0.65)$. Elevated wet deposition fluxes of $\mathrm{Hg}$ at urban sites of China were associated with the elevated VWM $\mathrm{Hg}$ concentrations in precipitation (Fig. 6a). Wet deposition fluxes of $\mathrm{Hg}$ in China were also positively correlated with ground-level TGM/GEM, PBM, and GOM concentrations (Fig. 6b, c, and d). Wet deposition of $\mathrm{Hg}$ has been suggested to result from the scavenging of PBM and GOM in cloud (i.e., rainout) and below cloud (i.e., washout) (Seigneur et al., 2004; Lin et al., 2006). In North America, a modeling study suggests that scavenging of GOM in and below cloud contributed mostly $(\sim 89 \%)$ to wet deposition of 
$\mathrm{Hg}$, with $\sim 41 \%$ contributed by washout (Selin and Jacob, 2008). In China, ground-based measurements of GOM in urban areas found that the mean GOM concentrations (means: $47.9 \mathrm{pg} \mathrm{m}^{-3}$, Fig. 5e, Fu et al., 2011; Xu et al., 2015) were 5.4 times greater than the mean $\left(8.9 \mathrm{pg} \mathrm{m}^{-3}\right)$ in North America (Swartzendruber et al., 2006; Yatavelli et al., 2006; Valente et al., 2007; Fain et al., 2009; Peterson et al., 2009; Song et al., 2009; Engle et al., 2010; L. Zhang et al., 2012). Scavenging of GOM in the continental boundary layer (i.e., washout) would therefore contribute to the elevated wet deposition fluxes of $\mathrm{Hg}$ at urban sites of China. It should be noted that PBM concentrations were also highly elevated (mean: $239 \pm 102 \mathrm{pg} \mathrm{m}^{-3}$ ) in the urban areas of China, which were 10-20 times greater than the levels observed in North America and Europe, and approximately 5 times greater than the mean GOM concentrations at the same locations (Fig. 5d and e). Lee et al. (2001) estimated that washout of PBM contributed approximately $1.0 \mu \mathrm{g} \mathrm{m}^{-2} \mathrm{yr}^{-1}$ to the total $\mathrm{Hg}$ deposition in the United Kingdom at a background PBM concentration of $10 \mathrm{pg} \mathrm{m}^{-3}$. Given the mean PBM concentration in urban areas of China, the mean flux of washout of PBM below cloud is roughly estimated to be $24 \mu \mathrm{g} \mathrm{m}^{-2} \mathrm{yr}^{-1}$, which explains approximately $90 \%$ of the mean wet $\mathrm{Hg}$ deposition flux in the urban areas of China. Since scavenging of PBM below cloud also depends on other factors, including the vertical distribution of PBM, intensity of precipitation, and cloud base height (Tanner et al., 1997; Hicks, 2005; Brooks et al., 2014), the estimate may have large uncertainties. Nevertheless, the estimate is in agreement with the measured fraction of particulate mercury $\left(\mathrm{Hg}_{\mathrm{p}}\right)$ in wet deposition flux of $\mathrm{Hg}$ at an urban site in China. Huang et al. (2013) found that $\sim 86 \%$ of the annual wet deposition of $\mathrm{Hg}$ in Lhasa of the Tibetan Plateau was associated with $\mathrm{Hg}_{\mathrm{p}}$, much higher than that at a rural site in the Tibetan Plateau (55\%, Huang et al., 2015) as well as at rural and urban sites in North America (26-63\%, Burke et al., 1995; Lamborg et al., 1995; Poissant and Pilote, 1998). These suggest the scavenging of PBM below cloud was an important contributor to the elevated wet deposition fluxes of $\mathrm{Hg}$ at urban sites of China.

On the other hand, mean wet deposition flux of $\mathrm{Hg}$ $\left(5.6 \pm 4.2 \mu \mathrm{g} \mathrm{m}^{-2} \mathrm{yr}^{-1}\right)$ at the rural sites of China was relatively lower (by a factor of 1.2 to 1.7) compared to those measured in North America $\left(9.5 \pm 4.2 \mu \mathrm{g} \mathrm{m}^{-2} \mathrm{yr}^{-1}\right)$ and Europe $\left(6.8 \pm 3.2 \mu \mathrm{g} \mathrm{m}^{-2} \mathrm{yr}^{-1}\right)$ (EMEP; Prestbo and Gay, 2009). This regional pattern is different from model results that predicted higher wet deposition in China because of large anthropogenic Hg emissions (Bergan et al., 1999; Dastoor and Larocque, 2004). There are several possible explanations for the lower wet deposition fluxes of $\mathrm{Hg}$ observed in the rural areas of China. Wet deposition fluxes of $\mathrm{Hg}$ at the rural sites of China were mostly observed in arid, semi-arid, and subhumid climate zones in northwestern and northeastern China (i.e., MWLG, MCB, and BYBLK in this study, Nam Co, and SET stations), where the precipitation depth is generally low (260-975 mm, data from this study and the literature, Huang et al., 2012, 2015) and anthropogenic Hg sources are scarce (X. T. Zhang et al., 2015). The remaining four rural sites (i.e., MDM, MLG, and MAL in this study, and Mt. Simian, Ma et al., 2016) were all located in mountaintop forests. Although the observations at some of these sites showed elevated PBM concentrations (mean: 31-154 $\mathrm{pg} \mathrm{m}^{-3}$ ) (Fu et al., 2015b; Yu et al., 2015), washout of PBM below cloud was not expected to contribute significantly to $\mathrm{Hg}$ in precipitation because of low cloud base heights (Ray et al., 2006). In addition, observations of GOM at high-altitude sites in China (i.e., MWLG, MAL, and Shangri-La) showed mean concentrations of 2$8 \mathrm{pg} \mathrm{m}^{-3}$ (Fu et al., 2012a, b; H. Zhang et al., 2015), significantly lower than those $\left(20-87 \mathrm{pg} \mathrm{m}^{-3}\right)$ measured at highaltitude sites in North America and Europe (Swartzendruber et al., 2006; Fain et al., 2009; Weiss-Penzias et al., 2009; Fu et al., 2016). Relatively lower GOM concentrations at the high-altitude sites in China were possibly due to the elevated atmospheric particulate matters in China that facilitate the partitioning of GOM to the particulate phase (Slemr et al., 2009; Swartzendruber et al., 2009; van Donkelaar et al., 2010; Amos et al., 2012; Zhang et al., 2013). Since the scavenging of GOM in the free troposphere and continental boundary layer is an important source of wet deposition of $\mathrm{Hg}$ (Selin and Jacob, 2008), the lower GOM concentrations in the rural areas of China could be responsible for the lower wet deposition fluxes of $\mathrm{Hg}$ observed in the rural areas of China.

Annual fluxes of $\mathrm{Hg}$ through litterfall at the rural sites in this and previous studies in China ranged from 22.8 to $62.8 \mu \mathrm{g} \mathrm{m}^{-2} \mathrm{yr}^{-1}$ (mean: $37.8 \pm 14.8 \mu \mathrm{g} \mathrm{m}^{-2} \mathrm{yr}^{-1}, n=6$, Fig. $5 \mathrm{~b}$; data are from this study and the literature, Fu et al., 2010b; Ma et al., 2016). Hg fluxes through litterfall in the rural areas of China were 1.4-4.7 times higher than the means observed in North America $\left(13.3 \pm 5.8 \mu \mathrm{g} \mathrm{m}^{-2} \mathrm{yr}^{-1}\right)$ and Europe $\left(16.5 \pm 8.7 \mathrm{\mu g} \mathrm{m}^{-2} \mathrm{yr}^{-1}\right)$ (Munthe et al., 1995; Rea et al., 1996; Lee et al., 2000; Schwesig and Matzner, 2000; St. Louis et al., 2001; Lindberg et al., 2007; Larssen et al., 2008; Fisher and Wolfe, 2012; Juillerat et al., 2012; Risch et al., 2012), but approximately 2.2 times lower than those (mean: $84.4 \pm 49.0 \mu \mathrm{g} \mathrm{m}^{-2} \mathrm{yr}^{-1}$ ) measured in South America (Roulet et al., 1998; Fostier et al., 2003; Mélières et al., 2003; Magarelli and Fostier, 2005; Silva-Filho et al., 2006; Teixeira et al., 2012). Global $\mathrm{Hg}$ fluxes through litterfall were positively correlated with both $\mathrm{Hg}$ concentrations in litterfall $\left(r^{2}=0.69, p<0.01\right)$ and litterfall biomass production $\left(r^{2}=\right.$ $0.70, p<0.01$ ) (Fig. 7). Forward stepwise multiple regression analysis suggests that litterfall biomasses and $\mathrm{Hg}$ concentrations in litterfall explained 69.2 and $25.4 \%$ of the regional variations in litterfall $\mathrm{Hg}$ fluxes, respectively. Productions of litterfall biomasses at the rural sites of China ranged from 434 to $1100 \mathrm{~g} \mathrm{~m}^{-2} \mathrm{yr}^{-1}$ (mean: $661 \pm 307 \mathrm{~g} \mathrm{~m}^{-2} \mathrm{yr}^{-1}$, $n=6$ ) and were approximately 2 times higher than that in North America and Europe (Munthe et al., 1995; Rea et al., 1996; Lee et al., 2000; Schwesig and Matzner, 2000; St. Louis et al., 2001; Lindberg et al., 2007; Larssen et al., 

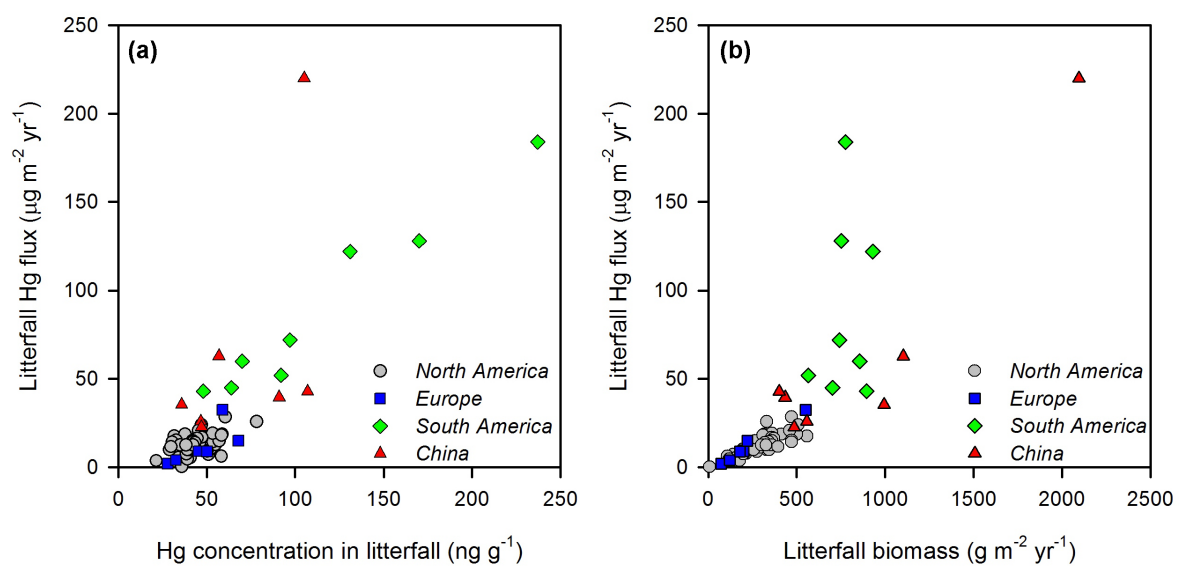

Figure 7. Scatterplot of (a) $\mathrm{Hg}$ concentrations in litterfall and litterfall fluxes of $\mathrm{Hg}$, and (b) litterfall biomasses and litterfall fluxes of $\mathrm{Hg}$ for the global observations. Data are from this study and the literature (Iverfeldt, 1991; Rea et al., 1996; Roulet et al., 1998; Fostier et al., 2000; Grigal et al., 2000; Schwesig and Matzner, 2000; St. Louis et al., 2001; Mélières et al., 2003; Magarelli and Fostier, 2005; Sheehan et al., 2006; Silva-Filho et al., 2006; Demers et al., 2007; Wangberg et al., 2007; Bushey et al., 2008; Larssen et al., 2008; Wang et al., 2009; Fu et al., 2010b; Fisher and Wolfe, 2012; Juillerat et al., 2012; Risch et al., 2012; Teixeira et al., 2012; Benoit et al., 2013; Ma et al., 2016).

2008; Fisher and Wolfe, 2012; Juillerat et al., 2012; Risch et al., 2012), which is the dominant factor causing the difference in litterfall $\mathrm{Hg}$ fluxes between China and North America/Europe. It is worth noting that most (five out of the six) observations at the rural sites of China were made in subtropical moist forests, where the litterfall biomass productions are larger than those in the temperate and boreal forests in North America and Europe (Xiong and Nilsson, 1997; Running et al., 2004; Wang et al., 2008). Additionally, mean $\mathrm{Hg}$ concentrations in litterfall at the rural sites of China $\left(63.3 \pm 29.0 \mathrm{ng} \mathrm{g}^{-1}\right)$ were elevated by a factor of $1.4 \mathrm{com}-$ pared to that $\left(44.0 \pm 10.4 \mathrm{ng} \mathrm{g}^{-1}\right)$ in North America and Europe (Munthe et al., 1995; Rea et al., 1996; Lee et al., 2000; Schwesig and Matzner, 2000; St. Louis et al., 2001; Lindberg et al., 2007; Larssen et al., 2008; Fisher and Wolfe, 2012; Juillerat et al., 2012; Risch et al., 2012). This could be partly attributed to the elevated TGM concentrations (Fig. 5c) and longer "leaf maintenance" period at most rural sites in China (Frescholtz et al., 2003; Poissant et al., 2008; Gustin, 2012; Fu et al., 2015b).

\section{Conclusions}

In this study, we analyzed the concentrations and deposition fluxes of $\mathrm{Hg}$ through precipitation and litterfall at multiple sites across a broad geographic area in mainland China. The VWM Hg concentrations and deposition fluxes of $\mathrm{Hg}$ in precipitation at rural sites were 3.7 to $7.7 \mathrm{ng} \mathrm{L}^{-1}$ (mean: $5.6 \pm 2.0 \mathrm{ng} \mathrm{L}^{-1}$ ) and 2.0 to $7.2 \mu \mathrm{g} \mathrm{m}^{-2} \mathrm{yr}^{-1}$ (mean: $\left.4.8 \pm 2.2 \mu \mathrm{g} \mathrm{m}^{-2} \mathrm{yr}^{-1}\right)$, respectively, lower than the VWM $\mathrm{Hg}$ concentration $\left(11.9 \pm 6.1 \mathrm{ng} \mathrm{L}^{-1}\right)$ and deposition fluxes of $\mathrm{Hg}\left(12.6 \pm 6.5 \mu \mathrm{g} \mathrm{m}^{-2} \mathrm{yr}^{-1}\right)$ at the urban GY site. Elevated wet deposition fluxes of $\mathrm{Hg}$ in urban areas of China corresponded to the elevated ground-level atmospheric $\mathrm{Hg}$ concentrations, indicating $\mathrm{Hg}$ scavenging below cloud was an important source of wet deposition of $\mathrm{Hg}$ in the urban areas of China. The wet deposition fluxes of $\mathrm{Hg}$ at the rural sites in this study, however, were lower than the observations in North America and Europe, and different from previous model results, possibly due to a combination of low precipitation depth and low cloud base heights and the low GOM concentrations in the troposphere in China. $\mathrm{Hg}$ fluxes through litterfall at the sampling sites ranged from 22.8 to $62.8 \mu \mathrm{g} \mathrm{m}^{-2}$, significantly higher (by a factor of 3.9 to 8.7 ) than the wet deposition fluxes in China and the litterfall deposition fluxes in North America and Europe, indicating that litterfall deposition contributes significantly to the total $\mathrm{Hg}$ deposition budget in forest ecosystems in China.

\section{Data availability}

Mercury $(\mathrm{Hg})$ concentrations in precipitation and litterfall at the sampling sites were measured by the authors of this paper, and the data sets of rain depth were provided by the filed stations monitored in this study. These data sets can be obtained by contacting Xuewu Fu (fuxuewu@ mail.gyig.ac.cn).

Acknowledgements. This work was financially funded by the National 973 Program of China (2013CB430003), the National Science Foundation of China (41473025, 41622305, 41430754, 41273145), the Global Mercury Observation System (GMOS) as part of FP7 (contract no. 265113) funded by the European Commission, and the CAS "Light of West China" program. We especially acknowledge the technicians that help to collect samples at the sampling sites. 
Edited by: N. Pirrone

Reviewed by: two anonymous referees

\section{References}

Amos, H. M., Jacob, D. J., Holmes, C. D., Fisher, J. A., Wang, Q., Yantosca, R. M., Corbitt, E. S., Galarneau, E., Rutter, A. P., Gustin, M. S., Steffen, A., Schauer, J. J., Graydon, J. A., Louis, V. L. St., Talbot, R. W., Edgerton, E. S., Zhang, Y., and Sunderland, E. M.: Gas-particle partitioning of atmospheric $\mathrm{Hg}$ (II) and its effect on global mercury deposition, Atmos. Chem. Phys., 12, 591-603, doi:10.5194/acp-12-591-2012, 2012.

Amos, H. M., Jacob, D. J., Streets, D. G., and Sunderland, E. M.: Legacy impacts of all-time anthropogenic emissions on the global mercury cycle, Global Biogeochem. Cy., 27, 410-421, doi:10.1002/gbc.20040, 2013.

Amos, H. M., Sonke, J. E., Obrist, D., Robins, N., Hagan, N., Horowitz, H. M., Mason, R. P., Witt, M., Hedgecock, I. M., Corbitt, E. S., and Sunderland, E. M.: Observational and modeling constraints on global anthropogenic enrichment of mercury, Environ. Sci. Technol., 49, 4036-4047, doi:10.1021/es5058665, 2015.

Benoit, J. M., Cato, D. A., Denison, K. C., and Moreira, A. E.: Seasonal Mercury Dynamics in a New England Vernal Pool, Wetlands, 33, 887-894, doi:10.1007/s13157-013-0447-4, 2013.

Bergan, T., Gallardo, L., and Rodhe, H.: Mercury in the global troposphere: a three-dimensional model study, Atmos. Environ., 33, 1575-1585, doi:10.1016/S1352-2310(98)00370-7, 1999.

Brooks, S., Ren, X. R., Cohen, M., Luke, W. T., Kelley, P., Artz, R., Hynes, A., Landing, W., and Martos, B.: Airborne vertical profiling of mercury speciation near Tullahoma, TN, USA, Atmosphere-Basel, 5, 557-574, doi:10.3390/atmos5030557, 2014.

Burke, J., Hoyer, M., Keeler, G., and Scherbatskoy, T.: Wet Deposition of Mercury and Ambient Mercury Concentrations at a Site in the Lake Champlain Basin, Water Air Soil Poll., 80, 353-362, doi:10.1007/Bf01189685, 1995.

Bushey, J. T., Nallana, A. G., Montesdeoca, M. R., and Driscoll, C. T.: Mercury dynamics of a northern hardwood canopy, Atmos. Environ., 42, 6905-6914, doi:10.1016/j.atmosenv.2008.05.043, 2008.

Chen, L. G., Liu, M., Xu, Z. C., Fan, R. F., Tao, J., Chen, D. H., Zhang, D. Q., Xie, D. H., and Sun, J. R.: Variation trends and influencing factors of total gaseous mercury in the Pearl River Delta-A highly industrialised region in South China influenced by seasonal monsoons, Atmos. Environ., 77, 757-766, doi:10.1016/j.atmosenv.2013.05.053, 2013.

Choi, H. D., Holsen, T. M., and Hopke, P. K.: Atmospheric mercury $(\mathrm{Hg})$ in the Adirondacks: concentrations and sources, Environ. Sci. Technol., 42, 5644-5653, doi:10.1021/Es7028137, 2008.

Dai, L. M., Qi, L., Wang, Q. W., Su, D. K., Yu, D. P., Wang, Y., Ye, Y. J., Jiang, S. W., and Zhao, W.: Changes in forest structure and composition on Changbai Mountain in Northeast China, Ann. Forest Sci., 68, 889-897, doi:10.1007/s13595-011-0095-x, 2011.

Dastoor, A. P. and Larocque, Y.: Global circulation of atmospheric mercury: a modelling study, Atmos. Environ., 38, 147-161, doi:10.1016/j.atmosenv.2003.08.037, 2004.
Demers, J. D., Driscoll, C. T., Fahey, T. J., and Yavitt, J. B.: Mercury cycling in litter and soil in different forest types in the Adirondack region, New York, USA, Ecol. Appl., 17, 13411351, doi:10.1890/06-1697.1, 2007.

Driscoll, C. T., Mason, R. P., Chan, H. M., Jacob, D. J., and Pirrone, N.: Mercury as a Global Pollutant: Sources, Pathways, and Effects, Environ. Sci. Technol., 47, 4967-4983, doi:10.1021/Es305071v, 2013.

Durnford, D., Dastoor, A., Figueras-Nieto, D., and Ryjkov, A.: Long range transport of mercury to the Arctic and across Canada, Atmos. Chem. Phys., 10, 6063-6086, doi:10.5194/acp-10-60632010, 2010.

EMEP: European Monitoring and Evaluation Programme (EMEP) Website, available at: http://www.emep.int/, last access: 2015.

Engle, M. A., Tate, M. T., Krabbenhoft, D. P., Schauer, J. J., Kolker, A., Shanley, J. B., and Bothner, M. H.: Comparison of atmospheric mercury speciation and deposition at nine sites across central and eastern North America, J. Geophys. Res.-Atmos., 115, D18306, doi:10.1029/2010jd014064, 2010.

Ericksen, J. A. and Gustin, M. S.: Foliar exchange of mercury as a function of soil and air mercury concentrations, Sci. Total Environ., 324, 271-279, doi:10.1016/j.scitotenv.2003.10.034, 2004.

Faïn, X., Obrist, D., Hallar, A. G., Mccubbin, I., and Rahn, T.: High levels of reactive gaseous mercury observed at a high elevation research laboratory in the Rocky Mountains, Atmos. Chem. Phys., 9, 8049-8060, doi:10.5194/acp-9-8049-2009, 2009.

Fisher, L. S. and Wolfe, M. H.: Examination of mercury inputs by throughfall and litterfall in the Great Smoky Mountains National Park, Atmos. Environ., 47, 554-559, doi:10.1016/j.atmosenv.2011.10.017, 2012.

Fostier, A. H., Forti, M. C., Guimaraes, J. R. D., Melfi, A. J., Boulet, R., Santo, C. M. E., and Krug, F. J.: Mercury fluxes in a natural forested Amazonian catchment (Serra do Navio, Amapa State, Brazil), Sci. Total Environ., 260, 201-211, doi:10.1016/S00489697(00)00564-7, 2000.

Fostier, A. H., Cecon, K., and Forti, M. C.: Urban influence on litterfall trace metals fluxes in the Atlantic forest of Sao Paulo (Brazil), J. Phys. Iv, 107, 491-494, doi:10.1051/Jp4:20030348, 2003.

Frescholtz, T. F., Gustin, M. S., Schorran, D. E., and Fernandez, G. C. J.: Assessing the source of mercury in foliar tissue of quaking aspen, Environ. Toxicol. Chem., 22, 2114-2119, doi:10.1897/1551-5028(2003)022<2114:Atsomi>2.0.Co;2, 2003.

Fu, X. W., Feng, X. B., Zhu, W. Z., Zheng, W., Wang, S. F., and Lu, J. Y.: Total particulate and reactive gaseous mercury in ambient air on the eastern slope of the Mt. Gongga area, China, Appl. Geochem., 23, 408-418, doi:10.1016/j.apgeochem.2007.12.018, 2008.

Fu, X. W., Feng, X., Dong, Z. Q., Yin, R. S., Wang, J. X., Yang, Z. R., and Zhang, H.: Atmospheric gaseous elemental mercury (GEM) concentrations and mercury depositions at a high-altitude mountain peak in south China, Atmos. Chem. Phys., 10, 24252437, doi:10.5194/acp-10-2425-2010, 2010a.

Fu, X. W., Feng, X. B., Zhu, W. Z., Rothenberg, S., Yao, H., and Zhang, H.: Elevated atmospheric deposition and dynamics of mercury in a remote upland forest of southwestern China, Environ. Pollut., 158, 2324-2333, doi:10.1016/j.envpol.2010.01.032, 2010 b. 
Fu, X. W., Feng, X. B., Qiu, G. L., Shang, L. H., and Zhang, H.: Speciated atmospheric mercury and its potential source in Guiyang, China, Atmos. Environ., 45, 4205-4212, doi:10.1016/j.atmosenv.2011.05.012, 2011.

Fu, X. W., Feng, X., Liang, P., Deliger, Zhang, H., Ji, J., and Liu, P.: Temporal trend and sources of speciated atmospheric mercury at Waliguan GAW station, Northwestern China, Atmos. Chem. Phys., 12, 1951-1964, doi:10.5194/acp-12-1951-2012, 2012a.

Fu, X. W., Feng, X., Shang, L. H., Wang, S. F., and Zhang, H.: Two years of measurements of atmospheric total gaseous mercury (TGM) at a remote site in Mt. Changbai area, Northeastern China, Atmos. Chem. Phys., 12, 4215-4226, doi:10.5194/acp12-4215-2012, 2012b.

Fu, X. W., Zhang, H., Lin, C.-J., Feng, X. B., Zhou, L. X., and Fang, S. X.: Correlation slopes of GEM / CO, GEM / $\mathrm{CO}_{2}$, and GEM $/ \mathrm{CH}_{4}$ and estimated mercury emissions in China, South Asia, the Indochinese Peninsula, and Central Asia derived from observations in northwestern and southwestern China, Atmos. Chem. Phys., 15, 1013-1028, doi:10.5194/acp-15-1013-2015, 2015 a.

Fu, X. W., Zhang, H., Yu, B., Wang, X., Lin, C.-J., and Feng, X. B.: Observations of atmospheric mercury in China: a critical review, Atmos. Chem. Phys., 15, 9455-9476, doi:10.5194/acp-15-94552015, 2015b.

Fu, X., Marusczak, N., Heimbürger, L.-E., Sauvage, B., Gheusi, F., Prestbo, E. M., and Sonke, J. E.: Atmospheric mercury speciation dynamics at the high-altitude Pic du Midi Observatory, southern France, Atmos. Chem. Phys., 16, 5623-5639, doi:10.5194/acp16-5623-2016, 2016.

Gratz, L. E., Keeler, G. J., and Miller, E. K.: Long-term relationships between mercury wet deposition and meteorology, Atmos. Environ., 43, 6218-6229, doi:10.1016/j.atmosenv.2009.08.040, 2009.

Grigal, D. F., Kolka, R. K., Fleck, J. A., and Nater, E. A.: Mercury budget of an upland-peatland watershed, Biogeochemistry, 50, 95-109, doi:10.1023/A:1006322705566, 2000.

Guo, Y. N., Feng, X. B., Li, Z. G., He, T. R., Yan, H. Y., Meng, B., Zhang, J. F., and Qiu, G. L.: Distribution and wet deposition fluxes of total and methyl mercury in Wujiang River Basin, Guizhou, China, Atmos. Environ., 42, 7096-7103, doi:10.1016/j.atmosenv.2008.06.006, 2008.

Gustin, M. S.: Exchange of mercury between the atmosphere and treestrial ecosystems, in: Environmental Chemistry and Toxicology of Mercury, First Edition, edited by: Liu, G. L., Cai, Y., and O’Driscoll, N. J., John Wiley \& Sons, Inc., 423-452, 2012.

Gustin, M. S., Amos, H. M., Huang, J., Miller, M. B., and Heidecorn, K.: Measuring and modeling mercury in the atmosphere: a critical review, Atmos. Chem. Phys., 15, 5697-5713, doi:10.5194/acp-15-5697-2015, 2015.

Hicks, B. B.: A climatology of wet deposition scavenging ratios for the United States, Atmos. Environ., 39, 1585-1596, doi:10.1016/j.atmosenv.2004.10.039, 2005.

Holmes, C. D., Jacob, D. J., Corbitt, E. S., Mao, J., Yang, X., Talbot, R., and Slemr, F.: Global atmospheric model for mercury including oxidation by bromine atoms, Atmos. Chem. Phys., 10, 12037-12057, doi:10.5194/acp-10-12037-2010, 2010.

Huang, J., Kang, S. C., Zhang, Q. G., Yan, H. Y., Guo, J. M., Jenkins, M. G., Zhang, G. S., and Wang, K.: Wet deposition of mercury at a remote site in the Tibetan Plateau: Concen- trations, speciation, and fluxes, Atmos. Environ., 62, 540-550, doi:10.1016/j.atmosenv.2012.09.003, 2012.

Huang, J., Kang, S. C., Wang, S. X., Wang, L., Zhang, Q. G., Guo, J. M., Wang, K., Zhang, G. S., and Tripathee, L.: Wet deposition of mercury at Lhasa, the capital city of Tibet, Sci. Total Environ., 447, 123-132, doi:10.1016/j.scitotenv.2013.01.003, 2013.

Huang, J., Kang, S. C., Zhang, Q. G., Guo, J. M., Sillanpaa, M., Wang, Y. J., Sun, S. W., Sun, X. J., and Tripathee, L.: Characterizations of wet mercury deposition on a remote high-elevation site in the southeastern Tibetan Plateau, Environ. Pollut., 206, 518-526, doi:10.1016/j.envpol.2015.07.024, 2015.

Iverfeldt, A.: Mercury in forest canopy throughfall water and its relation to atmospheric deposition, Water Air Soil Poll., 56, 553564, doi:10.1007/Bf00342299, 1991.

Johnson, D. W. and Lindberg, S. E.: The Biogeochemical Cycling of $\mathrm{Hg}$ in Forests - Alternative Methods for Quantifying Total Deposition and Soil Emission, Water Air Soil Poll., 80, 10691077, doi:10.1007/Bf01189767, 1995.

Juillerat, J. I., Ross, D. S., and Bank, M. S.: Mercury in litterfall and upper soil horizons in forested ecosystems in Vermont, USA, Environ. Toxicol. Chem., 31, 1720-1729, doi:10.1002/Etc.1896, 2012.

Lamborg, C. H., Fitzgerald, W. F., Vandal, G. M., and Rolfhus, K. R.: Atmospheric mercury in northern Wisconsin - Sources and species, Water Air Soil Poll., 80, 189-198, doi:10.1007/Bf01189667, 1995.

Landis, M. S. and Keeler, G. J.: Critical evaluation of a modified automatic wet-only precipitation collector for mercury and trace element determinations, Environ. Sci. Technol., 31, 2610-2615, doi:10.1021/Es9700055, 1997.

Larssen, T., de Wit, H. A., Wiker, M., and Halse, K.: Mercury budget of a small forested boreal catchment in southeast Norway, Sci. Total Environ., 404, 290-296, doi:10.1016/j.scitotenv.2008.03.013, 2008.

Lee, D. S., Nemitz, E., Fowler, D., and Kingdon, R. D.: Modelling atmospheric mercury transport and deposition across Europe and the UK, Atmos. Environ., 35, 5455-5466, doi:10.1016/S13522310(01)00284-9, 2001.

Lee, Y. H., Bishop, K. H., and Munthe, J.: Do concepts about catchment cycling of methylmercury and mercury in boreal catchments stand the test of time? Six years of atmospheric inputs and runoff export at Svartberget, northern Sweden, Sci. Total Environ., 260, 11-20, doi:10.1016/S0048-9697(00)00538-6, 2000.

Li, J., Sommar, J., Wangberg, I., Lindqvist, O., and Wei, S. Q.: Short-time variation of mercury speciation in the urban of Goteborg during GOTE-2005, Atmos. Environ., 42, 8382-8388, doi:10.1016/j.atmosenv.2008.08.007, 2008.

Lin, C. J., Pongprueksa, P., Lindberg, S. E., Pehkonen, S. O., Byun, D., and Jang, C.: Scientific uncertainties in atmospheric mercury models I: Model science evaluation, Atmos. Environ., 40, 2911 2928, doi:10.1016/j.atmosenv.2006.01.009, 2006.

Lindberg, S., Bullock, R., Ebinghaus, R., Engstrom, D., Feng, X. B., Fitzgerald, W., Pirrone, N., Prestbo, E., and Seigneur, C.: A synthesis of progress and uncertainties in attributing the sources of mercury in deposition, Ambio, 36, 19-32, doi:10.1579/00447447(2007)36[19:ASOPAU]2.0.CO;2, 2007.

Lindberg, S. E. and Stratton, W. J.: Atmospheric mercury speciation: Concentrations and behavior of reactive gaseous 
mercury in ambient air, Environ. Sci. Technol., 32, 49-57, doi:10.1021/Es970546u, 1998.

Liu, N., Qiu, G. G., Landis, M. S., Feng, X. B., Fu, X. W., and Shang, L. H.: Atmospheric mercury species measured in Guiyang, Guizhou province, southwest China, Atmos. Res., 100, 93-102, doi:10.1016/j.atmosres.2011.01.002, 2011.

Lyman, S. N., Gustin, M. S., Prestbo, E. M., and Marsik, F. J.: Estimation of dry deposition of atmospheric mercury in Nevada by direct and indirect methods, Environ. Sci. Technol., 41, 19701976, doi:10.1021/Es062323m, 2007.

Mélières, M. A., Pourchet, M., Charles-Dominique, P., and Gaucher, P.: Mercury in canopy leaves of French Guiana in remote areas, Sci. Total Environ., 311, 261-267, doi:10.1016/S0048-9697(03)00142-6, 2003.

Ma, M., Wang, D., Du, H., Sun, T., Zhao, Z., Wang, Y., and Wei, S.: Mercury dynamics and mass balance in a subtropical forest, southwestern China, Atmos. Chem. Phys., 16, 4529-4537, doi:10.5194/acp-16-4529-2016, 2016.

Magarelli, G. and Fostier, A. H.: Influence of deforestation on the mercury air/soil exchange in the Negro River Basin, Amazon, Atmos. Environ., 39, 7518-7528, doi:10.1016/j.atmosenv.2005.07.067, 2005.

Millhollen, A. G., Gustin, M. S., and Obrist, D.: Foliar mercury accumulation and exchange for three tree species, Environ. Sci. Technol., 40, 6001-6006, doi:10.1021/Es0609194, 2006.

Munthe, J., Hultberg, H., and Iverfeldt, A.: Mechanisms of Deposition of Methylmercury and Mercury to Coniferous Forests, Water Air Soil Poll., 80, 363-371, doi:10.1007/Bf01189686, 1995.

Munthe, J., Wangberg, I., Iverfeldt, A., Lindqvist, O., Stromberg, D., Sommar, J., Gardfeldt, K., Petersen, G., Ebinghaus, R., Prestbo, E., Larjava, K., and Siemens, V.: Distribution of atmospheric mercury species in Northern Europe: final results from the MOE project, Atmos. Environ., 37, S9-S20, doi:10.1016/S1352-2310(03)00235-8, 2003.

NADP: Mercury Deposition Network, National Atmospheric Deposition Program, available at: http://nadp.sws.uiuc.edu/mdn/ (last access: 2016), 1994.

Peterson, C., Gustin, M., and Lyman, S.: Atmospheric mercury concentrations and speciation measured from 2004 to 2007 in Reno, Nevada, USA, Atmos. Environ., 43, 4646-4654, doi:10.1016/j.atmosenv.2009.04.053, 2009.

Pirrone, N., Ferrara, R., Hedgecock, I. M., Kallos, G., Mamane, Y., Munthe, J., Pacyna, J. M., Pytharoulis, I., Sprovieri, F., Voudouri, A., and Wangberg, I.: Dynamic processes of mercury over the Mediterranean region: results from the Mediterranean Atmospheric Mercury Cycle System (MAMCS) project, Atmos. Environ., 37, S21-S39, doi:10.1016/S1352-2310(03)00251-6, 2003.

Pirrone, N., Cinnirella, S., Feng, X., Finkelman, R. B., Friedli, H. R., Leaner, J., Mason, R., Mukherjee, A. B., Stracher, G. B., Streets, D. G., and Telmer, K.: Global mercury emissions to the atmosphere from anthropogenic and natural sources, Atmos. Chem. Phys., 10, 5951-5964, doi:10.5194/acp-10-59512010, 2010.

Poissant, L. and Pilote, M.: Mercury concentrations in single event precipitation in southern Quebec, Sci. Total Environ., 213, 6572, doi:10.1016/S0048-9697(98)00076-X, 1998.

Poissant, L., Pilote, M., Yumvihoze, E., and Lean, D.: Mercury concentrations and foliage/atmosphere fluxes in a maple forest ecosystem in Quebec, Canada, J. Geophys. Res.-Atmos., 113, D10307, doi:10.1029/2007jd009510, 2008.

Prestbo, E. and Gay, D. A.: Wet deposition of mercury in the U.S. and Canada, 1996-2005: Results and analysis of the NADP mercury deposition network (MDN), Atmos. Environ., 43, 42234233, 2009.

Price, R. M., Swart, P. K., and Willoughby, H. E.: Seasonal and spatial variation in the stable isotopic composition (delta(18) O and delta D) of precipitation in south Florida, J. Hydrol., 358, 193-205, doi:10.1016/j.jhydrol.2008.06.003, 2008.

Ray, D. K., Nair, U. S., Lawton, R. O., Welch, R. M., and Pielke, R. A.: Impact of land use on Costa Rican tropical montane cloud forests: Sensitivity of orographic cloud formation to deforestation in the plains, J. Geophys. Res.-Atmos., 111, D02108, doi:10.1029/2005jd006096, 2006.

Rea, A. W., Keeler, G. J., and Scherbatskoy, T.: The deposition of mercury in throughfall and litterfall in the lake champlain watershed: A short-term study, Atmos. Environ., 30, 3257-3263, doi:10.1016/1352-2310(96)00087-8, 1996.

Risch, M. R., DeWild, J. F., Krabbenhoft, D. P., Kolka, R. K., and Zhang, L. M.: Litterfall mercury dry deposition in the eastern USA, Environ. Pollut., 161, 284-290, doi:10.1016/j.envpol.2011.06.005, 2012.

Roulet, M., Lucotte, M., Saint-Aubin, A., Tran, S., Rheault, I., Farella, N., Da Silva, E. D., Dezencourt, J., Passos, C. J. S., Soares, G. S., Guimaraes, J. R. D., Mergler, D., and Amorim, M.: The geochemistry of mercury in central Amazonian soils developed on the Alter-do-Chao formation of the lower Tapajos River Valley, Para state, Brazil, Sci. Total Environ., 223, 1-24, doi:10.1016/S0048-9697(98)00265-4, 1998.

Running, S. W., Nemani, R. R., Heinsch, F. A., Zhao, M. S., Reeves, M., and Hashimoto, H.: A continuous satellite-derived measure of global terrestrial primary production, Bioscience, 54, 547560, doi:10.1641/0006-3568(2004)054[0547:Acsmog]2.0.Co;2, 2004.

Schwesig, D. and Matzner, E.: Pools and fluxes of mercury and methylmercury in two forested catchments in Germany, Sci. Total Environ., 260, 213-223, doi:10.1016/S0048-9697(00)005659, 2000.

Seigneur, C., Vijayaraghavan, K., Lohman, K., Karamchandani, P., and Scott, C.: Global source attribution for mercury deposition in the United States, Environ. Sci. Technol., 38, 555-569, doi:10.1021/Es034109t, 2004.

Selin, N. E. and Jacob, D. J.: Seasonal and spatial patterns of mercury wet deposition in the United States: Constraints on the contribution from North American anthropogenic sources, Atmos. Environ., 42, 5193-5204, doi:10.1016/j.atmosenv.2008.02.069, 2008.

Selin, N. E., Jacob, D. J., Park, R. J., Yantosca, R. M., Strode, S., Jaegle, L., and Jaffe, D.: Chemical cycling and deposition of atmospheric mercury: Global constraints from observations, J. Geophys. Res.-Atmos., 112, D02308, doi:10.1029/2006jd007450, 2007.

Selin, N. E., Jacob, D. J., Yantosca, R. M., Strode, S., Jaegle, L., and Sunderland, E. M.: Global 3-D land-ocean-atmosphere model for mercury: Present-day versus preindustrial cycles and anthropogenic enrichment factors for deposition, Global Biogeochem. Cy., 22, Gb2011, doi:10.1029/2007gb003040, 2008. 
Shah, V., Jaeglé, L., Gratz, L. E., Ambrose, J. L., Jaffe, D. A., Selin, N. E., Song, S., Campos, T. L., Flocke, F. M., Reeves, M., Stechman, D., Stell, M., Festa, J., Stutz, J., Weinheimer, A. J., Knapp, D. J., Montzka, D. D., Tyndall, G. S., Apel, E. C., Hornbrook, R. S., Hills, A. J., Riemer, D. D., Blake, N. J., Cantrell, C. A., and Mauldin III, R. L.: Origin of oxidized mercury in the summertime free troposphere over the southeastern US, Atmos. Chem. Phys., 16, 1511-1530, doi:10.5194/acp-16-1511-2016, 2016.

Sheehan, K. D., Fernandez, I. J., Kahl, J. S., and Amirbahman, A.: Litterfall mercury in two forested watersheds at Acadia National Park, Maine, USA, Water Air Soil Poll., 170, 249-265, doi:10.1007/s11270-006-3034-y, 2006.

Shetty, S. K., Lin, C. J., Streets, D. G., and Jang, C.: Model estimate of mercury emission from natural sources in East Asia, Atmos. Environ., 42, 8674-8685, doi:10.1016/j.atmosenv.2008.08.026, 2008.

Silva-Filho, E. V., Machado, W., Oliveira, R. R., Sella, S. M., and Lacerda, L. D.: Mercury deposition through litterfall in an Atlantic Forest at Ilha Grande, southeast Brazil, Chemosphere, 65, 2477-2484, doi:10.1016/j.chemosphere.2006.04.053, 2006.

Slemr, F., Ebinghaus, R., Brenninkmeijer, C. A. M., Hermann, M., Kock, H. H., Martinsson, B. G., Schuck, T., Sprung, D., van Velthoven, P., Zahn, A., and Ziereis, H.: Gaseous mercury distribution in the upper troposphere and lower stratosphere observed onboard the CARIBIC passenger aircraft, Atmos. Chem. Phys., 9, 1957-1969, doi:10.5194/acp-9-1957-2009, 2009.

Song, S., Selin, N. E., Soerensen, A. L., Angot, H., Artz, R., Brooks, S., Brunke, E.-G., Conley, G., Dommergue, A., Ebinghaus, R., Holsen, T. M., Jaffe, D. A., Kang, S., Kelley, P., Luke, W. T., Magand, O., Marumoto, K., Pfaffhuber, K. A., Ren, X., Sheu, G.-R., Slemr, F., Warneke, T., Weigelt, A., Weiss-Penzias, P., Wip, D. C., and Zhang, Q.: Top-down constraints on atmospheric mercury emissions and implications for global biogeochemical cycling, Atmos. Chem. Phys., 15, 7103-7125, doi:10.5194/acp-157103-2015, 2015.

Song, X. J., Cheng, I., and Lu, J.: Annual atmospheric mercury species in Downtown Toronto, Canada, J. Environ. Monitor., 11, 660-669, doi:10.1039/B815435j, 2009.

Sprovieri, F., Pirrone, N., Ebinghaus, R., Kock, H., and Dommergue, A.: A review of worldwide atmospheric mercury measurements, Atmos. Chem. Phys., 10, 8245-8265, doi:10.5194/acp10-8245-2010, 2010.

St. Louis, V. L., Rudd, J. W. M., Kelly, C. A., Hall, B. D., Rolfhus, K. R., Scott, K. J., Lindberg, S. E., and Dong, W.: Importance of the forest canopy to fluxes of methyl mercury and total mercury to boreal ecosystems, Environ. Sci. Technol., 35, 3089-3098, doi:10.1021/Es001924p, 2001.

Strode, S. A., Jaegle, L., Jaffe, D. A., Swartzendruber, P. C., Selin, N. E., Holmes, C., and Yantosca, R. M.: Trans-Pacific transport of mercury, J. Geophys. Res.-Atmos., 113, D15305, doi:10.1029/2007jd009428, 2008.

Swartzendruber, P. C., Jaffe, D. A., Prestbo, E. M., Weiss-Penzias, P., Selin, N. E., Park, R., Jacob, D. J., Strode, S., and Jaegle, L.: Observations of reactive gaseous mercury in the free troposphere at the Mount Bachelor Observatory, J. Geophys. Res.-Atmos., 111, D24301, doi:10.1029/2006jd007415, 2006.

Swartzendruber, P. C., Jaffe, D. A., and Finley, B.: Development and First Results of an Aircraft-Based, High Time Resolution Technique for Gaseous Elemental and Reactive (Oxi- dized) Gaseous Mercury, Environ. Sci. Technol., 43, 7484-7489, doi:10.1021/Es901390t, 2009.

Tanner, P. A., Lei, H. C., Huang, M. Y., and Shen, Z. L.: Acid rain and below-cloud scavenging in south-western China, J. Atmos. Chem., 27, 71-78, doi:10.1023/A:1005852700933, 1997.

Teixeira, D. C., Montezuma, R. C., Oliveira, R. R., and Silva, E. V.: Litterfall mercury deposition in Atlantic forest ecosystem from SE - Brazil, Environ. Pollut., 164, 11-15, doi:10.1016/j.envpol.2011.10.032, 2012.

USEPA: Method 1631, Revision E: Mercury in Water by Oxidation, Purge and Trap, and Cold Vapor Atomic Fluorescence Spectrometry, United States Environmental Protection Agency, Washington, DC, USA, 10-46, 2002.

Valente, R. J., Shea, C., Humes, K. L., and Tanner, R. L.: Atmospheric mercury in the Great Smoky Mountains compared to regional and global levels, Atmos. Environ., 41, 1861-1873, doi:10.1016/j.atmosenv.2006.10.054, 2007.

van Donkelaar, A., Martin, R. V., Brauer, M., Kahn, R., Levy, R., Verduzco, C., and Villeneuve, P. J.: Global Estimates of Ambient Fine Particulate Matter Concentrations from Satellite-Based Aerosol Optical Depth: Development and Application, Environ. Health Persp., 118, 847-855, doi:10.1289/Ehp.0901623, 2010.

Vermette, S. J., Peden, M. E., Willoughby, T. C., Lindberg, S. E., and Weiss, A. D.: Methodology for the Sampling of Metals in Precipitation - Results of the National Atmospheric Deposition Program (Nadp) Pilot Network, Atmos. Environ., 29, 12211229, 1995.

Wang, J. X.: Study on total gaseous mercury in the southern Tibetan Plateau (in Chinese), Doctor's dissertation, Cold and Arid Regions Environmental and Engineeriing Research Institute Chinese Academy of Sciences, Beijing, 135 pp., 2006.

Wang, Q., Zhao, P., Ren, H., and Kakubari, Y.: Spatiotemporal dynamics of forest net primary production in China over the past two decades, Global Planet. Change, 61, 267-274, doi:10.1016/j.gloplacha.2006.12.007, 2008.

Wang, S. X., Zhang, L., Wang, L., Wu, Q. R., Wang, F. Y., and Hao, J. M.: A review of atmospheric mercury emissions, pollution and control in China, Front. Env. Sci. Eng., 8, 631-649, doi:10.1007/s11783-014-0673-x, 2014.

Wang, X., Lin, C.-J., Yuan, W., Sommar, J., Zhu, W., and Feng, X.: Emission-dominated gas exchange of elemental mercury vapor over natural surfaces in China, Atmos. Chem. Phys. Discuss., doi:10.5194/acp-2016-314, in review, 2016.

Wang, Y. M., Wang, D. Y., Meng, B., Peng, Y. L., Zhao, L., and Zhu, J. S.: Spatial and temporal distributions of total and methyl mercury in precipitation in core urban areas, Chongqing, China, Atmos. Chem. Phys., 12, 9417-9426, doi:10.5194/acp-12-94172012, 2012.

Wang, Y. M., Peng, Y. L., Wang, D. Y., and Zhang, C.: Wet deposition fluxes of total mercury and methylmercury in core urban areas, Chongqing, China, Atmos. Environ., 92, 87-96, doi:10.1016/j.atmosenv.2014.03.059, 2014.

Wang, Z. W., Zhang, X. S., Xiao, J. S., Zhijia, C., and Yu, P. Z.: Mercury fluxes and pools in three subtropical forested catchments, southwest China, Environ. Pollut., 157, 801-808, doi:10.1016/j.envpol.2008.11.018, 2009.

Wangberg, I., Munthe, J., Berg, T., Ebinghaus, R., Kock, H. H., Temme, C., Bieber, E., Spain, T. G., and Stolk, A.: Trends in air concentration and deposition of mercury in the coastal environ- 
ment of the North Sea Area, Atmos. Environ., 41, 2612-2619, doi:10.1016/j.atmosenv.2006.11.024, 2007.

Weiss-Penzias, P., Gustin, M. S., and Lyman, S. N.: Observations of speciated atmospheric mercury at three sites in Nevada: Evidence for a free tropospheric source of reactive gaseous mercury, J. Geophys. Res.-Atmos., 114, D14302, doi:10.1029/2008jd011607, 2009.

Xiong, S. J. and Nilsson, C.: Dynamics of leaf litter accumulation and it effects on riparian vegetation: A review, Bot. Rev., 63, 240-264, doi:10.1007/Bf02857951, 1997.

Xu, L. L., Chen, J. S., Yang, L. M., Yin, L. Q., Yu, J. S., Qiu, T. X., and Hong, Y. W.: Characteristics of total and methyl mercury in wet deposition in a coastal city, Xiamen, China: Concentrations, fluxes and influencing factors on $\mathrm{Hg}$ distribution in precipitation, Atmos. Environ., 99, 10-16, doi:10.1016/j.atmosenv.2014.09.054, 2014.

Xu, L. L., Chen, J. S., Yang, L. M., Niu, Z. C., Tong, L., Yin, L. Q., and Chen, Y. T.: Characteristics and sources of atmospheric mercury speciation in a coastal city, Xiamen, China, Chemosphere, 119, 530-539, doi:10.1016/j.atmosenv.2014.09.054, 2015.

Yatavelli, R. L. N., Fahrni, J. K., Kim, M., Crist, K. C., Vickers, C. D., Winter, S. E., and Connell, D. P.: Mercury, PM2.5 and gaseous co-pollutants in the Ohio River Valley region: Preliminary results from the Athens supersite, Atmos. Environ., 40, 6650-6665, doi:10.1016/j.atmosenv.2006.05.072, 2006.

Yu, B., Wang, X., Lin, C. J., Fu, X. W., Zhang, H., Shang, L. H., and Feng, X. B.: Characteristics and potential sources of atmospheric mercury at a subtropical near-coastal site in East China, J. Geophys. Res.-Atmos., 120, 8563-8574, doi:10.1002/2015JD023425, 2015.

Yuan, C. M., Liu, W. Y., Tang, C. Q., and Li, X. S.: Species composition, diversity, and abundance of lianas in different secondary and primary forests in a subtropical mountainous area, SW China, Ecol. Res., 24, 1361-1370, doi:10.1007/s11284-0090620-7, 2009.

Yuan, S. L., Zhang, Y. Y., Chen, J. B., Kang, S. C., Zhang, J., Feng, X. B., Cai, H. M., Wang, Z. H., Wang, Z. W., and Huang, Q.: Large variation of mercury isotope composition during a single precipitation event at Lhasa City, Tibetan Plateau, China, Proced. Earth Plan. Sc., 13, 282-286, doi:10.1016/j.proeps.2015.07.066, 2015.

Zhang, H., Fu, X. W., Lin, C.-J., Wang, X., and Feng, X. B.: Observation and analysis of speciated atmospheric mercury in ShangriLa, Tibetan Plateau, China, Atmos. Chem. Phys., 15, 653-665, doi:10.5194/acp-15-653-2015, 2015.

Zhang, H., Fu, X., Lin, C.-J., Shang, L., Zhang, Y., Feng, X., and Lin, C.: Monsoon-facilitated characteristics and transport of atmospheric mercury at a high-altitude background site in southwestern China, Atmos. Chem. Phys. Discuss., doi:10.5194/acp2016-506, in review, 2016.
Zhang, L., Blanchard, P., Gay, D. A., Prestbo, E. M., Risch, M. R., Johnson, D., Narayan, J., Zsolway, R., Holsen, T. M., Miller, E. K., Castro, M. S., Graydon, J. A., Louis, V. L. St., and Dalziel, J.: Estimation of speciated and total mercury dry deposition at monitoring locations in eastern and central North America, Atmos. Chem. Phys., 12, 4327-4340, doi:10.5194/acp-12-43272012, 2012.

Zhang, L., Wang, S. X., Wang, L., and Hao, J. M.: Atmospheric mercury concentration and chemical speciation at a rural site in Beijing, China: implications of mercury emission sources, Atmos. Chem. Phys., 13, 10505-10516, doi:10.5194/acp-1310505-2013, 2013.

Zhang, L., Wang, S. X., Wang, L., Wu, Y., Duan, L., Wu, Q. R., Wang, F. Y., Yang, M., Yang, H., Hao, J. M., and Liu, X.: Updated Emission Inventories for Speciated Atmospheric Mercury from Anthropogenic Sources in China, Environ. Sci. Technol., 49, 3185-3194, doi:10.1021/Es504840m, 2015.

Zhang, L. M., Wright, L. P., and Blanchard, P.: A review of current knowledge concerning dry deposition of atmospheric mercury, Atmos. Environ., 43, 5853-5864, doi:10.1016/j.atmosenv.2009.08.019, 2009.

Zhang, X. T., Siddiqi, Z., Song, X. J., Mandiwana, K. L., Yousaf, M., and Lu, J. L.: Atmospheric dry and wet deposition of mercury in Toronto, Atmos. Environ., 50, 60-65, doi:10.1016/j.atmosenv.2011.12.062, 2012.

Zheng, J. Y., Yin, Y. H., and Li, B. Y.: A New Scheme for Climate Regionalization in China (in Chinese), Acta Geographica Sinica, 65, 3-12, 2010.

Zhou, J., Feng, X. B., Liu, H. Y., Zhang, H., Fu, X. W., Bao, Z. D., Wang, X., and Zhang, Y. P.: Examination of total mercury inputs by precipitation and litterfall in a remote upland forest of Southwestern China, Atmos. Environ., 81, 364-372, doi:10.1016/j.atmosenv.2013.09.010, 2013.

Zhou, Y., Su, J. Q., Janssens, I. A., Zhou, G. S., and Xiao, C. W.: Fine root and litterfall dynamics of three Korean pine (Pinus koraiensis) forests along an altitudinal gradient, Plant Soil, 374, 1932, doi:10.1007/s11104-013-1816-8, 2014.

Zhu, J., Wang, T., Talbot, R., Mao, H., Hall, C. B., Yang, X., Fu, C., Zhuang, B., Li, S., Han, Y., and Huang, X.: Characteristics of atmospheric Total Gaseous Mercury (TGM) observed in urban Nanjing, China, Atmos. Chem. Phys., 12, 12103-12118, doi:10.5194/acp-12-12103-2012, 2012.

Zhu, J., Wang, T., Talbot, R., Mao, H., Yang, X., Fu, C., Sun, J., Zhuang, B., Li, S., Han, Y., and Xie, M.: Characteristics of atmospheric mercury deposition and size-fractionated particulate mercury in urban Nanjing, China, Atmos. Chem. Phys., 14, 22332244, doi:10.5194/acp-14-2233-2014, 2014. 